\title{
A History of the Bibliographical Society of Canada/La Société bibliographique du Canada: The First Fifty Years ${ }^{I}$
}

\author{
Liana Van der Bellen ${ }^{+}$
}

\section{Beginnings}

On 24 June I942, a trio of distinguished scholars Lorne Pierce, Editor of The Ryerson Press, Ernest Cockburn Kyte, Chief Librarian of Queen's University, and Marie Tremaine, the future doyenne of Canadian bibliography, met at The Ryerson Press editorial office in Toronto to consider the creation of a Canadian bibliographical society. ${ }^{2}$ Informal discussions and correspondence relating to this idea had been conducted for some time, ${ }^{3}$ but now a genuine commitment was made and a first executive formed with Pierce as President pro tem, Kyte as Vice-President (he was also to draft a project for a constitution), and Tremaine as Secretary. However, to quote Marie Tremaine: 'It was agreed that while these anxious days [of the Second World War] were not the time to launch a formal programme, the beginnings of a Canadian Society should be made.'

Who then were the founders of the Society? At the time Pierce (I 890-I96r) ${ }^{4}$ was one of the major figures in Canadian publishing. Editor since I920 of one of the oldest and most important publishing houses in Canada, he was instrumental in bringing out the works of a great number of Canadian writers and inaugurated many of the notable Ryerson series. Fellow of the Royal Society of Canada since 1926, he established the Society's gold medal in his name for outstanding contributions to Canadian literature. Author of many works on Canadian literature, history and art, Pierce was also a discerning collector of Canadiana, building up over the years the outstanding Edith and Lorne Pierce Collection of books, manuscripts and papers of Canadian writers at his alma mater, Queen's University. A firm believer in building 'a covered bridge between East and West; between French and English; between Catholic and

† Liana Van der Bellen retired in I99I from her position as Chief of the Rare Book Division, National Library of Canada. Member of the Society since 1962, she was president of the BSC in $1982-4$. 
Protestant ... 5 Pierce must be given credit for attracting several francophones to the Society in its early years, one of whom, Victor Morin became its first president.

Ernest Cockburn Kyte (1876-1971) ${ }^{6}$ came to Canada from Great Britain in 1928 on being appointed to the post of Chief Librarian at Queen's University. He brought with him a wealth of experience, which included work in public libraries and with the Library Association. As Consulting Librarian to the firm of J. and E. Bumpus of London, Booksellers to His Majesty King George v, he had occasion to work with prestigious private collections, such as that of the Duke of Marlborough at Blenheim and many others. Before leaving for Canada, he was Librarian at Sandringham of the private library of King George v. In his years at the Douglas Library, from 1928 to 1947, Kyte contributed much to the development and organization of its collections.

Kyte and Pierce were in close contact over Pierce's regular donations of books and manuscripts to the Library, and they became good friends, sharing their passion for Canadiana. Kyte was the author of many articles on bibliographical topics, a lecturer, and editor of early Canadian works. In 1946 he edited A Catalogue of Canadian Manuscripts Collected by Lorne Pierce and Presented to Queen's University (Toronto: Ryerson Press, 1946). The remark by Tremaine on Kyte is often referred to: 'I always felt that Mr. Kyte, the rare book connoisseur, so modest, humorous and gracious withal, conferred a benison on our (then feeble) little Society by his mere presence at the meetings. ${ }^{7}$

Marie Tremaine (1902-84) ${ }^{8}$ was then on the staff of the Reference Division of the Toronto Public Libraries where she had worked since her graduation from the Ontario Library School in 1927, with some time off for study and research on Carnegie Fellowships. One of the few university-trained bibliographers in Canada at the time, she studied at the University of London's School of Librarianship in 1929-30 with bibliographical luminaries such as Arundell Esdaile. (Freda Farrell Waldon of Hamilton Public Library would soon follow her to London, obtaining her diploma in I93 I.) From October 1935 to September 1937, with the support of two consecutive Carnegie Fellowship grants for study at Yale University, Tremaine was able to continue her research into early printing in Canada and to record eighteenth-century imprints. Intensive 'field work' followed in the form of visits to many libraries and archives in Canada and the United States, mainly in the period 1935 to 1937 , but in some cases extending up to I947. Years of dedicated research work cul- 
minated in her A Bibliography of Canadian Imprints, I75I-I800 (Toronto : University of Toronto Press, 1952). This scholarly descriptive bibliography with its extensive historical notes constitutes an invaluable contribution to the history of printing and publishing in Canada, and is a landmark work in the field of early Canadian imprint bibliography. ${ }^{9}$ Earlier, in the 1930 s and 1940s, Tremaine had already published articles and monographs on Canadian printing history ${ }^{\mathrm{IO}}$ as well as having co-edited with her colleague, Frances Staton, another important retrospective Canadiana bibliography based on the rich collections of the Toronto Public Libraries: $A$ Bibliography of Canadiana: Being Items in the Public Library of Toronto, Canada, Relating to the Early History of Canada (Toronto: Toronto Public Libraries, 1934). Through her work and research at institutional and private libraries and archives across the country, Tremaine was, of course, familiar with the riches as well as the inadequacies of the Canadian collections and their catalogues, so it is only fitting that she became one of the founders of a society that aimed to preserve and record Canada's printed heritage. She was also well aware of the activities and publications of the older societies, such as the Bibliographical Society (founded in Britain in I 892) and the Bibliographical Society of America (founded in 1904). In August I943, signing herself as Secretary, Tremaine sent letters to potential 'Foundation Members.' She referred to the earlier informal meetings and discussions and noted that a policy had been suggested and a constitution tentatively drawn up. She hoped that all parts of Canada would be represented, but that 'at the beginning the Society should be limited to a small number of recognized experts admitted by invitation, and that the standard aimed at should be as high as that of the work done abroad.' Three documents were enclosed with the letter: 'The Bibliographical Society of Canada: Rules for Membership and Constitution,' 'Memorandum Respecting the Bibliographical Society of Canada,' and 'Objects of the Canadian Bibliographical Society.' The first document outlined in seventeen points the Society's proposed organizational set-up and conditions of membership, and included many elements later incorporated into the constitution in a modified version. The name was to be The Bibliographical Society of Canada, and its 'objects' were as follows:

(a) The promotion and encouragement of bibliographical studies and of research into Canadian bibliography. 
(b) The acquisition and dissemination of information dealing with bibliography.

(c) The publication of bibliographical works, particularly those in the Canadian field.

It appears that at first the Society was to be fairly restrictive: 'Candidates for membership shall be proposed by a member, seconded by another member in writing, and submitted to the Executive Committee.' It was further noted that the 'Society shall consist of not more than one hundred members in the Dominion of Canada' but would admit or elect corresponding members from England and the United States. Institutions would be admitted and would be represented by their 'principal librarian or other official.' The membership fees were to be $\$$ Io.oo per year for individual members, $\$ 5.00$ for corresponding members. Institutions would have to pay an additional $\$ 3.00$ as an 'entrance fee.' The 'Memorandum' explained:

Our object in limiting the members in the first place to one hundred is to create a desire to belong. One hundred members at $\$ 10.00$ annually would give the Society wherewithal to exist. Its first critical years would enable it to bring out its first opuscula and to take stock of the field and of those that would labour therein. ${ }^{\text {II }}$

One concern was to assure adequate regional representation among the membership. The proposed roo members would come from various parts of the country (described as Maritime, Central, Prairie and the West Coast), with perhaps twenty people from each region. This would permit regional meetings to be held, at which papers on local bibliography would be read and eventually gathered together to form a definitive bibliography of Canada. At the same time, the Society through its members should aim to 'record, and so far as possible locate early and scarce books and pamphlets of the various regions of Canada.' Files of newspapers 'should be sought out and preserved locally' also. Research would be undertaken into the early printers, their presses, as well as the type and papers used. Beside the regional gatherings general meetings would be held which 'may be planned to take place coincidentally or occasionally in conjunction with that of some other national learned society. ${ }^{\text {I2 }}$

The third document, 'Objects of the Canadian Bibliographical Society,' begins by listing in Section I, under fourteen points various 
bibliographical projects to be undertaken which could form the basis of an ambitious publications programme. Section II reiterated the need for local groups to explore 'the history, traditions and records of their region; to prepare carefully documented papers on these; to have them read at local gatherings. . . .; preserve first editions, letters, minute books and other material related to their regions.' The Society itself would participate in the collecting and preservation projects. Section IIr proposed the founding of a central library of the Society consisting of materials collected 'with scrupulous care': 'specimens of first printings in different provinces and districts, early newspapers and periodicals, especially those out of print, MSs and illustrational materials of first importance. ${ }^{13} 3$ Section IV specified that the Society would publish Transactions.

If it seems that the founders of the Bibliographical Society of Canada did not place much confidence in local or regional libraries and archival institutions as gatherers, preservers, and recorders of retrospective Canadiana, it must be remembered that they were working and writing at a time when Canada still lacked a National Library ${ }^{14}$ and decades before the government-funded Canadian Institute for Historical Microreproductions would undertake its major Canadiana microfilming projects. ${ }^{15}$ As bibliographers, the early members keenly felt the absence of comprehensive Canadiana collections and services traditionally offered by a national library, and many among them became vocal supporters of the projects and proposals to found such a library for Canada. While national bibliographical control was still in the future, individual, and some institutional bibliographical endeavours in Canada date back to the end of the eighteenth century in the form of library and bookdealer catalogues. Traditionally the first Canadian bibliographer is considered to be Georges-Barthélemi Faribault (1789-I866), lawyer and public servant in Quebec City, who brought out in 1837 the Catalogue d'ouvrages sur l'histoire de l'Amérique et en particulier sur celle du Canada, de la Louisiane, de l'Acadie, et autres lieux, ci-devant connus sous le nom de Nouvelle-France ... (Quebec : W. Cowan, 1837). A comprehensive history of bibliography in Canada is yet to be written: an often quoted source is the article by W. Kaye Lamb, 'Seventy-five Years of Canadian Bibliography. ${ }^{16}$ Several publications give useful overviews of the developments in this field: the papers given at two of the three Colloquia (I and III) held by the Society in the $1970 \mathrm{~s}^{17}$ and the proceedings of the major national bibliographical conferences held in 1974, I98I and 1992 (the last organized by the Society|. ${ }^{18}$ 
A definitive step towards formal organization of the Society was taken in April I946, when Tremaine dispatched another letter (this time with a printed letterhead bearing the Society's name) to prospective members, inviting them to a meeting in May of the same year. The earlier letter had elicited a positive response from about thirty people between Vancouver and Halifax who showed a serious interest in the proposed society, many of whom agreed to become 'foundation members.' A new one-page concise document was attached to Tremaine's second letter reviewing the objects and touching on some organizational questions. Some revisions were no doubt made in response to remarks by future members. The objects are identical to the ones in the 1943 documents, except for a longer text for the first object: 'The promotion and encouragement of bibliographical studies and of research into Canadian bibliography on both the creative side and the technical side, both on the writers and their work, and on printers etc., and their work.' (This was later omitted). The limitation of membership to roo was dropped as well as the $\$ 10.00$ fee. In a further letter, dated 6 May, Tremaine indicated that the meeting was set for 20 May, and that Pierce would host a luncheon at the University Club in Toronto. She wrote: 'We will explore the prospects of organizing a Bibliographical Society in Canada, discuss problems involved, and decide whether to proceed or drop the project.'

Who were present at this crucial meeting, which is considered to be the founding event of the Society? The three members of the 'provisional executive': Pierce, Kyte, and Tremaine were, of course, there, as well as a group of eleven colleagues from the world of books and scholarship. It was a distinguished gathering, indeed, of women and men, several of whom were Fellows of the Royal Society of Canada.

The library profession was well represented: from the University of Toronto came Winifred Barnstead (1884-I985), long-time staff member of the Toronto Public Libraries and since 1928 Director / the first) of the University's Library School; W. Stewart Wallace (I 884I970), historian and Librarian of the University since 1923 and author of many historical and reference works, such as the sixvolume Encyclopedia of Canada (first edition, 1935-7), and the Macmillan Dictionary of Canadian Biography (first edition, 1926); Margaret V. Ray, Associate Librarian of Victoria College (now University), bibliographer of E.J. Pratt and Raymond Knister, the latter issued 'under the auspices' of the Society in 1950. Isabel Locheed (later Skelly, 1903-83), Reference Librarian at Hamilton Public Library, was also there. ${ }^{19}$ 
Three noted Ontario historians were present: Dr. Fred Landon (1880-1969), Professor of History and Librarian of the University of Western Ontario, and Dr. James J. Talman (I904-93), soon to succeed Landon as Chief Librarian at Western. From Queen's University came Dr. Reginald Trotter (1888-195 I), Head of the Department of History. The nation's capital was represented by a librarian and an archivist: The Rev. Auguste-Marie Morisset, o.m.i. (I900-89), Chief Librarian at the University of Ottawa since 1934 and founder of its Library School (École de bibliothécaires), in I938, and Dr. James F. Kenney, Director of Historical Research at the Public Archives of Canada since I9I 2 and acting Dominion Archivist from I935 to 1937. Representing the Toronto antiquarian book trade was Dora Hood, founder (in 1928) of Dora Hood's Book Room, for many years one of the most important book stores in that city specializing in out-of-print and rare Canadiana. ${ }^{20}$ From Montreal came two erudite bookmen. Victor Morin (1865-1960), ${ }^{21}$ influential member of the legal profession and leading figure in many cultural and professional associations, wrote extensively on legal and historical topics (among others a booklet on Fleury Mesplet in 1939). A noted bibliophile, his collection of some I 2,00o items, much of it Canadiana, was sold by the Librairie Ducharme in the I950s. Montreal's other representative, Gérard Malchelosse (1 896-1970), was then on the staff of the Bibliothèque Saint-Sulpice, which was founded by the Sulpicians in the nineteenth century. Malchelosse was soon to join the antiquarian book dealer Gonzague Ducharme as manager of his business, and he later became its owner.

Judging from the minutes of the 20 May meeting, ${ }^{22}$ the participants contributed many ideas and recommendations to the lively discussion on organizational questions, the importance of preserving and recording Canadiana, bibliographical research, and the eventual publication programme of the Society. Support and cooperation were offered by all. At the close of the session, Pierce was able to declare that 'the sense of the meeting pointed to the organization of a Bibliographical Society of Canada.' Thus, in the elegant surroundings of Toronto's University Club, the Society was born. A Nominating Committee was appointed to form an Executive and Council. It met on 22 May and presented the first slate of officers as follows: President, Victor Morin; First Vice-President, Fred Landon; Second Vice-President, W. Stewart Wallace; SecretaryTreasurer, Marie Tremaine; ${ }^{23}$ French Secretary, Gérard Malchelosse. Council members were: Winifred Barnstead, Maurice P. Boone, Gonzague Ducharme, E.C. Kyte, W. Kaye Lamb, and Rev. A.M. 
Morisset. Tremaine was also nominated as Chairman, Committee on Publications. The Executive was to prepare a constitution and statement of aims during the summer of 1946 . Pierce, the President pro tem, declined to be part of the Executive. However, he participated actively in the Society, offering counsel and financial support for publications, attending Council and Annual Meetings as Honorary President from 1948 until his death in 196r. Many of the 'founding members' were elected to the Executive and Council.

To the original group three new names must be added: Lamb, Boone, and Ducharme. Dr. W. Kaye Lamb (1904-), the noted historian, Librarian of the University of British Columbia, was soon to be named Dominion Archivist (1947), with the special assignment of preparing the way for the establishment of a National Library. It is not an exaggeration to say that during his career he achieved 'more than any other individual in Canadian history in the combined fields of archives, libraries and historical scholarship. ${ }^{24}$ President of the Society in 1952-4, Lamb kept members informed of the developments in Ottawa, and on becoming the first National Librarian in 1953, offered the full cooperation and support of this institution for the Society's bibliographical endeavours. Maurice P. Boone (I907-84) was named to the first Council. He was then Librarian of Acadia University in Wolfville, Nova Scotia, later Librarian of the Legislative Library of New Brunswick in Fredericton. Another Montrealer, Gonzague Ducharme (1875-1950) joined the Council. He was the owner of the Librairie Ducharme, probably the most important antiquarian book shop in the country at the time, with a large stock of Canadiana and Americana. Known for his wide knowledge of historical publications on Canada, he was noted for his meticulously researched catalogues. ${ }^{25}$

The first Annual Meeting of the Society was held on 7 June 1947 at the Library Club in Toronto. Membership recruitment and a publications programme were discussed at the meeting, and a constitution was adopted. It had been revised on the basis of several previous texts by Pierce and Morin, who later also prepared the French version. ${ }^{26}$ The organizational framework was thus in place. The Society was ready to begin its activities, cautiously at first, since as its second President, Fred Landon stated:

Launching a new Society in a field that is limited in public inter- est and whose membership is scattered from coast to coast, offers certain difficulties which your Officers and Council are seeking to surmount and in the working out of which they ask your further cooperation. ${ }^{27}$ 


\section{Organizational Responsibilities}

The affairs of the Society, as provided by the Constitution and By-Laws, lay in the hands of the Executive and Council. ${ }^{28}$ At first the Council was composed of a President, two Vice-Presidents, a Secretary-Treasurer and an Assistant Secretary (later Associate Secretaryl, the Secretaries being of the English or French language respectively, and six Councillors. The terminology was adjusted as functions changed and other officers were added: the Immediate Past-President, the Chairman of the Publications Committee, and, some time afterwards, the members of this Committee; the Editor of the Papers/Cahiers, the Book Review Editors(s), the Editor of the Bulletin, and the Indexer to the Society. Committee Chairmen were usually nominated from among Council members or participated ex-officio at Council meetings: Chairman of the Tremaine Medal Committee, Chairman of the Fellowships Committee, and Chairman of the Nominating Committee. An Indexing Committee functioned for some years. ${ }^{29}$ The Society's representatives (official or non-official) to Canadian or international bodies such as CBSC (Committee on Bibliographical Services for Canada) ${ }^{\circ}$ of the National Library's Advisory Board or ESTC (Eighteenth Century Short Title Catalogue ${ }^{3 \mathrm{I}}$ reported regularly to Council also. The number of Councillors was eventually augmented from the original six to nine, each serving a three-year term. Election of Officers and Council are prescribed by the Constitution and By-Laws. The work of the Executive and Council has, of course, always been performed on a voluntary basis. The Society has never been able to afford a permanent office or paid staff, the address of the Society being that of the Secretary-Treasurer or a postal box.

A period of stability was achieved for the Society in 1955, when Pierce invited Mrs. R.C. (Esther) Jacobsen to take on the responsibility of Secretary-Treasurer. A graduate of the Toronto Library School and later one of the first to obtain the Master of Library Science degree from the University of Toronto, Mrs. Jacobsen's professional expertise was in the field of special libraries. With wide interests in many other areas of librarianship as well as bibliography, she was for almost a quarter-century the advisor and councillor par excellence, keeping in touch with members near and far. Her home at 32 Lowther Avenue in downtown Toronto was the Society's address from I 955 until her retirement in 1979 and the focal point of the Society's activities and projects. With the unfailing support of her husband R.C. (Jake) Jacobsen, she also took 
charge of all practical matters, such as managing the Society's finances, recording the Council and Annual Meeting minutes, keeping membership records, storing the Society's files and publications, seeing its publications through the press, and, of course, keeping up the correspondence and taking care of the large mailings of publications to members. Mr. Jacobsen also devoted much time and energy to the Society's affairs, contributing the Society's letterhead, many attractive designs for scrolls and other honours, and in countless other ways until his death in 1986 . When Esther Jacobsen decided to retire in August 1979 and relinquished the position described by long-time member Father Morisset as 'secrétaire perpétuelle,' it was soon found that her tasks had to be divided among three officers and assigned to a Secretary, a Treasurer, and for all questions related to membership, to the 2nd Vice-President. In 1989 the Society recognized Mrs. Jacobsen's long and devoted service with an Honorary Life membership and, to further underline the Society's appreciation, presented her in 1994 with a specially designed scroll.

The Constitution and By-Laws stipulate that to conduct the Society's business at least two Council meetings were to be held in a year in the fall and in the spring. For various reasons, most Council meetings have been held in central Canada, with the overwhelming number in Toronto, with occasional excursions to Ottawa, and at least one in Atlantic Canada. ${ }^{32}$ In Toronto, the meetings have been held at institutions to which members of the Executive or Council have been affiliated: the University of Toronto's Faculty of Library and Information Science, Massey College, The Thomas Fisher Rare Book Library, the Metropolitan Toronto Public Library, etc. In recent years, when cost of air travel has made it difficult for distant Council members to go to Toronto, the spring Council meeting has taken place on the day prior to the Annual Meeting. Consultation and decision-making have also been effected over the telephone, by mail, and lately by electronic means of communication. Council meeting minutes have been kept regularly from the beginning, and, in conjunction with the minutes of the Annual Meetings, provide a source for the study of the development and functioning of the Society. ${ }^{33}$ There appear never to have been formal annual reports as such. Presidents and other Officers and Committee Chairmen have reported orally or in written form to Council and to the membership at large at Annual Meetings. These reports have been incorporated into the minutes. In earlier years Treasurer's reports merely recorded bank balances. Although not audited, the Society's state- 
ments of revenue, expenditure, and fund equity are currently calculated by means of a review engagement report in accordance with generally accepted accounting principles.

\section{Financial Matters}

The income of the Society has always been quite modest, deriving principally from membership fees. The total accumulation of fees has fluctuated with the number of members that the Society has been able to attract and maintain. Monetary gifts and sales of current and earlier publications and some royalties have provided additional income. The expenses have related to the following: the publication and distribution of monographs and serials (Bulletin, Newsletter, Papers/Cahiers, Bulletin, new series); the organization of Annual and Council meetings and Colloquia; travel expenses of speakers; and secretarial and office expenditures. Throughout its history the Society has had to seek additional funding for its major publications, both monographs and serials (particularly the Papers/ Cahiers) ${ }^{34}$ and for the costs related to meetings, in earlier years from the Canada Council and the Social Sciences and Humanities Councils, later from the Social Sciences and Humanities Research Council of Canada (sshrc). Funding has been requested and obtained from ssHRC's Administration and Travel Grants and Aid to Learned Journals programmes.

The Society has been fortunate in having received a substantial bequest $(\$ 30,000.00$ U.s.) from founding member and Honorary President, Marie Tremaine, at the time of her death in I984 'To be held by the Society as an endowment, the income from the said endowment to be used for such of the Society's purposes as its Council in its discretion may determine.' Profitably invested, it has been used for expenses related to the awarding of the Tremaine Medal and for an annual Fellowship. ${ }^{35}$ Another notable gift $(\$ 8,000.00)$ came to the Society from the Amtmann Circle, which was founded in 1979 by the Antiquarian Booksellers Association of Canada to commemorate its founding President, Bernard Amtmann (I 907-79), the eminent Montreal antiquarian book dealer and specialist in Canadiana. The Amtmann Circle ceased in 1989. The fund serves to support the work of scholars in Amtmann's principal areas of interest: Canadiana, book collecting, the book trade, and bibliography. ${ }^{36}$

In I982, the Society requested and was granted Charitable Organization status, and since then, it has been in the position to issue official receipts for gifts which may be used by donors to claim tax deductions. To encourage gifts, a note 'Means and purposes: a 
suggestion to our members and friends,' has been published for some years in issues of the Papers/Cahiers.

\section{Membership}

As previously noted, the original idea of a limited membership was soon discarded by the 'founders,' and in the earliest version of the Constitution, it was already stated that 'Any person or institution interested in the objects of this Society may become a member on the approval of the Council.' Besides the individual and institutional memberships, Life and Contributing memberships are offered (with a higher fee scale), while student and 'retired' members have reduced fees. The earlier category of 'corresponding member' has been discontinued. Honorary memberships are awarded to those 'considered by Council worthy of the Society's mark of distinction, for services rendered to Canadian bibliography or individual merit.' 37 The fees are voted at the Annual Meeting after a recommendation by Council, and have had to be increased over the years to keep up with inflation. ${ }^{38}$ Since the Society's income depends on fees paid by members, recruitment has been carried out in various ways to increase membership. Members are urged to add their personal efforts to make the Society, its aims, and activities more widely known and appreciated.

Publicity has been sent to pertinent institutions (libraries, library schools, academic faculties), to associations and journals with related interests. One of the most successful vehicles has been the brochure. An earlier version was issued in 1970 as an attractive booklet with notes on the Society's history and aims and a list of its publications. Although the Society's name was rendered in both English and French, the text was only in English. In I98I a new brochure was designed, this time fully bilingual, and with the Society's logo (a stylized hand press). It contains information on the Society's objects, publications, the Tremaine Medal and its winners, Fellowships, and a membership application form. In recent years brochures have been distributed in great numbers, and membership has fluctuated considerably. The highest figure in the history of the Society was recorded in I99r: 400 individual and roo institutional members. ${ }^{39}$ No doubt the fact that the Society now meets every other year with the Learned Societies has helped to attract academics. Earlier membership surveys have shown a preponderance of librarians..$^{\circ}$ An informal survey to assess the occupation or professional affiliation of members and their areas of interest was conducted in I98I. At the time /the figures were based on 127 
returns|, seventy-seven members were librarians, twenty-eight academics in the fields of literature, history, library science, history of medicine, and fifteen in the category 'others' (booksellers, bibliographers, archivists, geographers, etc.). The eighteen 'retired' members appear not to have specified their former occupation. The majority reported an orientation towards enumerative bibliography, but a great many also professed an interest in descriptive, analytical, textual, and historical bibliography. The Society, which has always aimed at country-wide representation, has occasionally done statistical analyses of its members' places of residence, such as the one published in the Bulletin, n.s., May 1989. It indicated the majority of members as living in Ontario, followed by Quebec, Alberta, British Columbia, and so on in diminishing numbers with one personal member in the Yukon.

Membership directories have been issued in the Bulletin and the Newsletter and for some years in the Papers/Cahiers. More recently, they have been issued irregularly in the form of lists. Membership news has been carried in the Bulletin and Newsletter also and continues to be part of the Bulletin, n.s.

\section{Publications: I940s and I950S}

From the first, the founders and early Councils emphasized the vital importance of publications in making the Society and its aims and activities better known. Indeed, as noted earlier, publications in their various forms, serials or monographs, have been the principal benefits of membership. The letters and documents sent to prospective members in the I 940 os contain many references to the Society's future publication programmes. It is also significant that Tremaine, the Secretary of the pro tem Executive, also consented to act as Editorial Secretary in anticipation of members' contributions to the proposed Transactions and their suggestions for monographs. Throughout the early correspondence she stressed that all publications, which the Society would undertake, must 'adhere to the highest standards of quality and bibliographical science.' In these early documents it is repeatedly stressed that the Society aimed to promote bibliographical research, to disseminate information dealing with bibliography, and to publish bibliographical works, particularly those in the Canadian field. These statements were, of course, reflected in the Constitution's objects. ${ }^{4 \mathrm{I}}$ It was hoped that papers generated at local or regional meetings of members would eventually be gathered together as a resource of history of printing and publishing and would take the shape of a definitive bibliography 
of Canada. One of the early documents includes an extensive 'wish list' of research projects.

At the founding meeting in May 1946, many opinions and suggestions regarding the publication plans of the Society were recorded in the minutes..$^{42}$ These are selectively cited here: there was general agreement that 'bibliographical material existed in Canada of a kind and quantity to warrant a publishing society'; 'the new society should publish material which does not find an outlet in existing journals.' Fred Landon is recorded as saying: 'The organization should get busy, stand on its own feet and publish something.' Somewhat optimistically, he also stated that the Society should not beg money from foundations, but 'do what we can from our own resources.' This would prove difficult due to the financial situation of the Society, and most of its major publications could not have been brought out without subsidies from funding agencies. Several of those present expressed the opinion that publishing reprints and making information known about scarce Canadian works would help to preserve and stimulate the collecting of Canadiana. A strong editorial committee was recommended by Kyte. The need for scholars to be able lo locate bibliographies outside their own field was stressed: a bibliography of bibliographies was proposed as a solution. Library school faculty members present promised cooperation, principally in making available bibliographies prepared by students in their course work. Finally, Pierce, with typical generosity, promised to 'undertake the publication of (the Society's) first monograph' and to 'underwrite for three years the publishing of its Transactions.' In the Society's formative years, and until his death in I96I, those who assumed the responsibility for the Society's publications benefited greatly from Pierce's unfailing support and advice. 43

The first publications of the Society were issued in 1949. In the modest Bulletin that appeared in May, the President, Fred Landon, reported that the first two monographs, rare Canadian pamphlets inaugurating the Reprint Series, had been distributed to members in the spring of the same year. They were: Thoughts on the Education of Youth (Newark, Upper Canada, 1795$)^{44}$ and Représentations par le Corps de Grands Jurés (Québec, 1765).45 Landon further noted: 'Since the Society is as yet entirely dependent upon membership fees for funds, and since this revenue is limited, no ambitious printing programme is possible at this stage of the Society's history. ${ }^{46} \mathrm{He}$ emphasized that these two reprints had been paid for from membership fees and that the continued support of members 
was needed to ensure that the Society 'will become a live force and active agency' in the field of Canadian bibliography.

The first Bulletin took the form of a 'letter' headed: 'To the members of the Bibliographical Society of Canada,' signed by the President and the Secretary, Donalda Putnam. Nine issues in all appeared between May 1949 and June 1952.47 The Bulletin had no editor but appears to have been put together by the President and the Secretary. The issues communicated to members news of the Society's activities, including general bibliographical news items. Reports and sometimes minutes of the Annual and other meetings were given as well as lists of Officers and Council members. Members' work in progress or published bibliographies were also listed..$^{8}$ Important events in the world of books and bibliography in the early I950s were noted, such as the creation in Ottawa of the Canadian Bibliographic Centre, and, shortly afterwards, of the National Library of Canada. The great publishing event of the era, of course, was the appearance of $A$ Bibliography of Canadian Imprints, I75I-I 800 by Tremaine in 1952, commented upon in enthusiastic terms by Father Morisset in the Bulletin as 'a real masterpiece .. . Unique bibliographic tool. . . '

A great deal of importance was attached to the monographs. Due to financial constraints, pamphlets only were considered for the Reprint Series, but each was chosen with great care in the hope of making available unique and scarce Canadiana. Members were continuously urged to select and submit titles and even unpublished manuscripts known to them or held by their institutions. Questionnaires were devised to elicit suggestions, and the results were published in the Bulletin (and later in the Newsletter). Much time was devoted to discussion and decision- making at Council meetings. Publications from all regions of the country were always considered, both in English and French. Four booklets were issued in the Reprint Series: modestly presented in mimeograph form with grey paper wrappers, the titles in dark blue black-letter type. They were truly cooperative ventures. Copies were made available by members' institutions in original, microfilm or photostat form. They often also assisted in the production process. Three hundred copies seems to have been the average print run. Members did research on the authors and the publishing history of the works chosen and provided scholarly introductions and notes. The first two issues of the Reprint Series, early upper Canadian and Quebec imprints have already been referred to. Two booklets from the West and the Atlantic provinces then appeared: Sawney's Letters 
(Barkerville, B.C., I 868 /49 $^{49}$ and a previously unpublished work, The Manuscript Book of Oliver Goldsmith, dating from the early nineteenth century. ${ }^{\circ \circ}$ At the Annual Meeting held in Banff in June 1952, the President, Father Morisset, announced that the mimeograph method of reproduction would be abandoned in favour of a 'newer more accurate process' in a Facsimile Series. He also announced publication of the first two titles in the new series: Aux citoyens et habitants des villes et des campagnes de la Province de Québec (Québec, 1785) ${ }^{5 \mathrm{I}}$ and The Union of Taste and Science: A Poem (Québec, I799) ) $^{52}$. These two publications put a considerable strain on the Society's financial resources. The cooperative work on the monographs continued, and between 1953 and 1957, four more facsimiles were issued: The Red River Expedition (Winnipeg, I 870), 53 Cree Syllabic Hymn Book (Norway House, 184I), ${ }^{54}$ The British American Almanack for the Year 1792 (Saint John, N.B., I79I),55 and Kensington Gardens in 1830 (London, I830). ${ }^{56}$ With these small monographs, the Society did pioneer work in searching out scarce Canadian imprints for reproduction and making them available at a modest cost. For years they were priced at $50 \AA$ each. The booklets were welcomed by members and the interested public.

In the middle 1950s, Pierce, now Honorary President, who kept a close paternal eye on the developments of the Society, advised Council to establish a long-term policy on publishing rather than proceeding with one isolated item at a time. He suggested the establishment of an editorial committee with the responsibility for planning and carrying out a publishing programme to ensure that 'the publications it issues might compare more favourably with those issued in England and the United States.' The Council followed this eminently sensible advice and created a Publications Committee in 1955 with R.D. Hilton Smith, then with the Toronto Public Libraries, as Chairman. He resigned soon afterwards and went to British Columbia where he began an antiquarian book business. He was succeeded by David W. Foley. ${ }^{57}$

I 955 saw the publication of a new serial, this time under the title Newsletter. It ran from I 955 to 1962 . With no reference to its predecessor, the first issue of the Newsletter carried an editorial note:

For some time, librarians, archivists and collectors in Canada have desired a medium of exchange of information on collections and items, and for the expression of ideas on matters of bibliographical interest. In an attempt to meet this need, it has been decided to issue a biannual Newsletter. ${ }^{58}$ 
There was a gap of three years between the last issue of the Bulletin and the appearance of the Newsletter's first issue. The Newsletter was also printed in mimeograph form, but on better quality paper than the Bulletin and was under the direction of an editor. The first two issues were edited by the Rev. George Boyle of Victoria University. Dr. David Hayne of the Department of French at the University of Toronto soon took over editorial responsibility for the journal, beginning a long and fruitful association with the Society. The Newsletter was issued quarterly, and the contents acquired substance. From the first it carried information and news related to the Society: lists of Executive and Council members, announcements and minutes of the Annual Meetings, with Presidential addresses and reports of the Chairman of the Publications Committee. Other organizational items printed in the Newsletter were: directories of members; questionnaires seeking input into the monograph publications programme, as well as lists of suggestions for publications; forms to assist members to submit their recent works for a yearly listing; price lists of the Society's publications; membership application forms, etc. Notices of bibliographical publications and new acquisitions of interest by institutions also appeared. An innovative development was the expansion of the contents: bibliographical notes on Canadian writers and their works began to be included (written mostly by the editor), occasional book reviews, and at least one article on library collections. For many years the Society had no suitable venue for the publication of the complete texts of addresses and papers given at the Annual Meetings. They were often published in other journals, such as the Bulletin of the Canadian Library Association, or, as in the case of the paper given by Dr. Guy Sylvestre at the 195 I Annual Meeting in Toronto, in the University of Toronto Quarterly, with offprints distributed free to members. Neal Harlow's 1952 paper 'Bibliographers in an Age of Science,' was first issued in the Revue de l'Université d'Ottawa and later reprinted as CLA's first Occasional paper. With the creation of the Newsletter, papers given at Annual Meetings were brought out, first in summary form, and later with the complete text. One special issue was dedicated to Pierce when he retired from his position as Editor of The Ryerson Press. ${ }^{59}$

From time to time concerns about the publications programme were voiced at Annual Meetings. These were reflected in the addresses of Presidents and Chairmen of the Publications Committee, a key position for many years. In a long and passionate speech given in French at the Annual Meeting in 1956, the President, 
Gérard Malchelosse, after a survey of the development of bibliography and the rich field of historical Canadiana, ended by optimistically predicting that in a few years, when the membership of the Society had reached the fabulous figure of 3,000 (and its income increased accordingly!) 'nous pourrions faire des grandes et belles choses.' At the same meeting, the Chairman of the Publications Committee, David W. Foley, in his lengthy report, stated that while the primary responsibility of the Committee continued to be the selection of rare items of Canadiana and their publication, 'more time will be taken in the future to establish priorities and a long range publications programme.' In addition to the Reprint Series and the Facsimile Series, consideration was to be given to a third series, to be known as the Bibliographical Series. As well, Foley stated, the Society should consider following the example of its British and American counterparts and should publish actual bibliographies, and perhaps begin by issuing as the next facsimile, a work that could be considered as the earliest Canadian bibliography, $A$ Catalogue of English and French Books in the Québec Library (Québec, 1785). This project was not realized. Due to lack of funds, Foley suggested that consideration should be given to joint publication with commercial publishers or agencies such as the National Library of Canada. To underline the importance of the position of the Chairman of the Publications Committee, this officer was added to the Council and an amendment to this effect was voted upon at the 1956 meeting.

Two years later, in another lengthy report to the 1958 Annual Meeting, Foley reiterated some of the same concerns, but he was able to announce the publication of the first original monograph of the Society: H. Pearson Gundy's paper read at the 1956 Meeting, now issued under the title, Early Printers and Printing in the Canadas. ${ }^{60}$ While the Newsletter was expending a large portion of the Society's limited funds, it was continued and was recognized as having considerable value to members. Several suggestions had been received in the hope that the Newsletter could be expanded into an even more substantial journal which would 'contain papers on Canadian bibliography and serve as means of communication among scholars.' It was realized that most of the members' fees would go into such a journal and that as a result, it would be difficult to continue the monograph series. Foley concluded his report by stating:

It may be remarked here that this Society has achieved miracles on a very short shoestring, largely through devoted private efforts. The 
work of the Society, however, suffers from severe limitations due to lack of funds. Bibliographical work is notoriously expensive, and as a result, the Society has often been excluded from participation in the most important projects undertaken in Canada.

In spite of the financial constraints, at the same meeting, Raymond Tanghe, Assistant National Librarian, launched the idea for the most ambitious publication project undertaken by the Society up to that time, the first purely bibliographical in nature and one for which the need had been felt for some time by Canadian scholars and librarians, namely a Bibliography of Canadian Bibliographies. It became the first major cooperative project of the Society, calling for the active participation of members across the country, and the first work undertaken in close association with the National Library.

While work on the Bibliography of Canadian Bibliographies, or ВCB as it came to be called, mobilized the energies of members, no other monographs were to be issued. The and augmented version of a list originally published by the McGill University Library School under the title: A Bibliography of Canadian Bibliographies, compiled by the 1929 and I930 classes in bibliography of the McGill University Library School under the direction of Marion V. Higgins (Montreal, I930). Authorized by McGill to use the title and the information contained in this forty-five page pamphlet, and to proceed with a revision, Tanghe asked members to contribute to the work by sending pertinent data to a coordinating committee. Later at the same meeting, Pierce, the Honorary President, moved: 'That the Society approve in principle Dr. Tanghe's suggestion that a Bibliography of Canadian Bibliographies be prepared, and that Dr. Tanghe be authorized to appoint a Committee to investigate this matter and to formulate plans for the compilation of the Bibliography.' In the Newsletter, the scope of the в Св was outlined and 'expressions of opinion and suggestions requested.' A Working Committee of some fourteen correspondents across Canada was formed to report on local bibliographies. Among the correspondents were many notable members: Bruce Peel for Alberta; H. Pearson Gundy for Ontario; Shirley Elliott for Nova Scotia; John Archer for Saskatchewan; Maurice Boone for New Brunswick; Agnes O'Dea for Newfoundland. Tanghe, who was continuing to fulfill his many duties as Assistant National Librarian, as well as starting to work on the retrospective national bibliography, acted as editor and was responsible for the overall coordination of 
the всв project. The National Librarian gave full support to the venture by encouraging staff participation. Martha Shepard was one of the 'correspondents,' but the person most often mentioned was Madeleine Pellerin, Tanghe's assistant for this undertaking, who also worked with him on the retrospective bibliography. One can follow the gradual formation of the Working Committee through issues of the Newsletter. Progress reports explain the scope, policies of inclusion and exclusion, the methodology, the form of entries, and so on. The work proceeded at considerable speed. By June 1959 800 titles had been recorded. In anticipation of the completion of the project Tanghe solicited and obtained grants from the Humanities and Social Sciences Research Councils of Canada. The Society, as expected, did not have sufficient funds to cover the cost of publication. He then approached the University of Toronto Press, which accepted the всв for publication. This was the first cooperative venture with the Press, to be continued for many years. The copyright at that time was assigned to the Press as publisher, and was to cover future editions also, although some years later the Society obtained sole copyright. The Press was to pay the Society, as sponsor, a royalty of $10 \%$ of the net price of all copies sold. In the Newsletter of March 1960, the publication of the ВСВ in June of that year was announced. At the Annual Meeting, held on 20 June at the Queen Elizabeth Hotel in Montreal, advance copies were released. Speaking to an audience of 200 , the number of Society members augmented by participants at a joint Canadian Library Association and American Library Association Conference, Tanghe gave an overview of the work accomplished. At the close of his presidential address, he noted:

In placing this little book in the lap of the Society, I hope that it will be kept up to date. This should not involve a great deal of work now that Canadian bibliographies are reported in Canadiana. A cumulated list could be published once a year in the Newsletter and thus every owner could bring his copy up to date. ${ }^{6 \mathrm{I}}$

\section{Publications: I960s and I970s}

The decade began with the completion and publication of the Bibliography of Canadian Bibliographies, the first such research tool for Canada. It was favourably received and reported as selling well in Canada and abroad, the royalties providing a small but steady income for future editions. Work had started immediately 
on updating the volume. The Newsletter of March I96I carried a first supplement. Three further supplements were issued separately. ${ }^{62}$ After the appearance of the 1960-6I supplement, Tanghe retired from the National Library and accepted a position in Paris. Pellerin alone was responsible for the two final supplements. Unfortunately, neither Tanghe nor Pellerin lived to see the publication of the second edition of the всв.

In 1962 David Hayne, the editor of the Newsletter, recommended to Council that the Society should cease to issue this quarterly and publish in its stead, beginning in the fall of that year, an annual volume of Papers of the Bibliographical Society of Canada / Cahiers de la Société bibliographique du Canada. ${ }^{63}$ Now, at last, the Society was able to realize more fully its aim to encourage bibliographical research and offer a medium for the publication of scholarly articles on Canadian topics. Editor and author of many other scholarly projects, Hayne was editor of the Papers/Cahiers for ten years, bringing out volumes I-XI (I962-72), and presiding over the development of the journal. ${ }^{64}$ The position of editor has remained one of the most important among the officers of the Council, carrying with it the responsibility for the continued excellence of the only Canadian journal dedicated to the publication of bibliographical studies. ${ }^{65} \mathrm{~A}$ major source for articles has been papers given at the Annual Meetings. To a great extent the contents of the Papers/ Cahiers reflect the development of research in Canadian bibliography.

In the decade from 1962 to 1972 , the responsibility for planning and carrying out the Society's publication plans and projects was under the capable and energetic direction of the Publications Chairman Douglas G. Lochhead, Professor of English at University College of the University of Toronto, as well as Librarian of Massey College. There, he established the first bibliographical press for the study and teaching of traditional hand-printing techniques to graduate students. A well-know poet, editor of literary works, bibliographer, printer, author of many studies on Canadian printing and publishing history, and Fellow of the Royal Society of Canada, Lochhead's concern for the scope and excellence of the Society's projects continued well beyond his term on the Publications Committee and as President of the Society (1974-6).

Monographs began to be published again in the 1960s. In I962, the index compiled by Mary Markham Brown to the important cultural periodical The Literary Garland: a Monthly Magazine, Devoted to the Advancement of General Literature, originally issued in Montreal by John Lovell from I 838 to I $85 \mathrm{I}$, was accepted for 
publication. ${ }^{66}$ One of the longest-running magazines of the early nineteenth century, The Literary Garland was a pioneer in publishing writing by Canadian authors in addition to materials reprinted from American and European publications. The fact that this important source for the study of nineteenth-century Canadian literature was being reprinted by an American company provided a further reason for issuing its Index. The first edition of H. Pearson Gundy's Early Printers and Printing in the Canadas being out of print, it was decided to bring out a second edition. It appeared in 1964 with some minor changes. In 1965 , the Society published another important contribution by Gundy to Canadian book history, Book Publishing and Publishers in Canada before 1900, with emphasis on the two largest publishing centres, Montreal and Toronto. ${ }^{67}$ Canada's centennial was marked by suitable publications. After much discussion, two nineteenth-century imprints were chosen for publication (an 'Eastern' and a 'Western' item): A.G. Gilbert's From Montreal to the Maritimes and Back (Montreal, I 867 ), ${ }^{68}$ and the Rev. G.O. Corbett's Notes on Rupert's America (London, I 868 ). ${ }^{69}$ In 1968 work began on a new edition of the Bibliography of Canadian Bibliographies (ВСв2), under Lochhead's direction, again, as in the case of the first edition, with the cooperation of bibliographers from all parts of the country. The research was completed in I970, with extensive indexing done by Peter E. Greig, also on staff at Massey College. The publication in 1972 of ВСB2 by the University of Toronto Press was again financially supported by a grant from the Humanities and Social Sciences Research Councils of Canada. ${ }^{70}$

In the late I96os the direction of the Society's publishing programme came under serious scrutiny by Council. It was felt that the programme should be expanded and more widely publicized. A study was done by Bruce Peel, and an enlarged Publications Committee with representation from all regions of the country was recommended. It was hoped that this would result in a more wide-ranging investigation of the availability of suitable materials for publication, would initiate more ambitious publishing projects, and would build up a reserve of articles for the Papers/Cahiers. The recommendation regarding an expanded Publications Committee was implemented, and for some years there were five representatives on the Committee from Halifax to Victoria. To further publicize the Society's aims and its publications a first brochure was prepared by Peel and Inglis Bell. The attractive booklet, designed at the University of British Columbia, was ready for distribution early in $1970 .{ }^{71}$ In 1972, H. Pearson Gundy (1905-94) succeeded 
Lochhead as Chairman of the Publications Committee, and remained in this position until I98I. Recently retired as University Librarian at Queen's, he was an early and active member of the Society, and, as previously noted, the author of important monographs on early Canadian printers and publishers. Following his official retirement, he was appointed Professor of Bibliography as well as of English Language and Literature at Queen's. Gundy was also editor of Queen's Quarterly and founder and Senior Editor of McGill-Queen's University Press. In the I 970 s some of the most substantial monographs of the Society were issued: W.F.E. Morley, Special Collections Librarian at Queen's University's Douglas Library and longtime Society member, had been working for some years on the bibliography of the writings of the nineteenth-century Canadian author, John Richardson (I796-I852), and had published a preliminary version in the Papers/Cahiers. He now offered an expanded text to the Society. It was accepted and appeared in 1973 as A Bibliographical Study of Major John Richardson, with an introduction by Derek F. Crawley. ${ }^{72}$ One of the most thorough bibliographical studies of a Canadian writer published up to that time, extensively annotated with a detailed publishing history of the individual works, it was a major contribution to Canadian literary bibliography.

In 1975 the last book of the Facsimile Series (no. 9), the I 846 Specimen of Printing Types ... of the Montreal publishing firm of John Lovell and Sons, was re-issued by the Society. ${ }^{73}$ In his introduction, Lochhead, as editor, noted that the book had clearly been designed to improve standards and to 'widen the range of printing practices among Canadian printers and publishers' in the nineteenth century. The two last monographs of the I 970 s were, in I 976 , Marilyn Flitton's Index to the Canadian Monthly and National Review (I 872-82),74 and the proceedings of Colloquium III held in Ottawa in the fall of 1978 and published in 1979 in the same format as the Papers/Cahiers (edited by Elizabeth Hulse). ${ }^{75}$ In the introduction to the Index Flitton remarked:

Up to the time of Confederation, the history of the Canadian periodical in English which had begun with the publication of the Nova Scotia Magazine in 1789, had been marked by a series of enthusiastic but generally short-lived adventures. But the times at last appeared to be favourable. From I 872 to I 882 , a small group of literary nationalists were able to produce a successful journal devoted to Canadian interests, the Canadian Monthly and National Review, (later Rose-Belford's Canadian Monthly and National Review). 
Unfortunately, by the end of the 1970s, increased production costs and limited finances severely restricted the possibilities for the Society to continue the publication of monographs. ${ }^{76}$ The 1970 s saw some developments related to the Bibliography of Canadian Bibliographies. As early as March 1972, a Standing Committee was appointed by Council to prepare another edition (ВСВ3). The Committee was composed of the editor of ВСB2, Douglas Lochhead, and Peter Greig. Later that year the need for a larger Committee was expressed, but this was never implemented. A comprehensive report was submitted to Council by the members of the Standing Committee at the fall 1976 meeting. Revised in May I977, it was published in the Papers/Cahiers. ${ }^{77}$ The report reviewed the history of the two previous editions, and proposed changes, in both the content and the structure of the вСв 3 . For instance, the scope was to be extended beyond monographic bibliographies, but would eliminate unpublished ones (this would omit a great number of library school generated lists). Items to be recorded would be examined by the compilers, and locations indicated. Entries would be annotated. The bibliographic style would be revised to be consistent with current standards. However, the alphabetical sequence of entries introduced in $\mathbf{B C B 2}$ would be retained.

Eventually, Lochhead resigned as Chairman. He recommended that Greig be appointed in his stead. Greig was at the time on the staff of the National Library. In response to a Resolution of the 1974 National Conference on the State of Canadian Bibliography, the Committee on Bibliographical Services for Canada of the National Library Advisory Board was established. Its Secretariat was located at the National Library, and Greig had been appointed Secretary. The files and the work on the всв thus moved back to the National Library where it had originated some seventeen years previously. Eventually, the National Library also agreed to house the files permanently after the completion of $\mathbf{B C} 33$, to assure updating and make the files accessible to the Society and to researchers. The fact that the СвSC was eventually to act as a clearinghouse for bibliographical work in Canada would also facilitate assembling records for в Св3. Work continued on the Bibliography for many years.

In the r 970 s the Society issued the Bulletin (new series) ${ }^{78}$, the need having been felt for a newsletter with notes about members, meetings, and developments in the bibliographical community. The first issue appeared in May 1973, and it has since been published twice a year, in the spring and in the fall. It was begun by the President, W.F.E. Morley and the Secretary, Esther Jacobsen, but an 
editor was soon appointed. Elizabeth Hulse served in this position from 1974 to 1978 , succeeded by Beth Miller, who was editor till I 984 then by Alvan Bregman (I985-8), Martin Dowding (I 988-90), and Merrill Distad (I99I-).

\section{Publications: I980s and I990s}

From 1982 to 1986 Peel $^{79}$ assumed the chairmanship of the Publications Committee. He expanded the membership of the Committee to include all the editors (Papers/Cahiers, Book Reviews, Bulletin) and the Indexer. Many important questions relating to yet another review of the publications policy and programme were considered and reported to Council. Several meetings were held in 1983 and I984, with the aim of re-establishing a policy. Pending the availability of suitable texts and, of course funds, various options were put forward: reprints of eighteenth- and nineteenth-century Canadian bibliographies still having relevance; a literary series, featuring bibliographical studies of individual authors (but excluding living authors); subject or topical bibliographies (regional, ethnic, etc.); the revival of the Society's earlier and very successful Reprint and Facsimile series of rare Canadian pamphlets; and perhaps broadsides. The ever present problem of limited financial resources of the Society had, of course, to be taken into account. The Papers/Cahiers continued to be a successful means to publish bibliographical studies. The scholarly standing of the journal was reinforced by the creation of an Editorial Board in 1986 when the Papers/Cahiers became a refereed journal.

A priority considered by the Publications Committee was the future of the ВCB3 , in view of the fact that Greig as editor had resigned in August $1983 .{ }^{80}$ Several options were discussed by the Publications Committee and Council. Did the Society possess the human and financial resources to carry the project through to completion? Would a supplement listing bibliographies published since 1973 be preferable to a revised and enlarged edition? Was there a need for a comprehensive bibliography in view of the increased development of computerized databases? When these questions were discussed by Council in the spring of I984, it was felt that the project would have to be shelved for the time being. At one point in 1985, the feasibility of the National Library's reference staff continuing work on ВСв was considered.

After Peel's resignation from the Publication's Committee in I 986-87, the Committee was chaired by another former President (I98I-83) and Tremaine Medal holder, Professor Gloria Strathern 
from University of Alberta's Faculty of Library and Information Studies, author of many important retrospective bibliographies of British Columbia and Alberta. ${ }^{81}$ The policy and mandate of the Committee again came under scrutiny, but publication projects were placed in abeyance due to lack of funds. In 1989, David Kotin, Head of the History Department at the Metropolitan Toronto Reference Library succeeded Strathern as Chairman. Formerly Head of the Canadiana section of the North York Public Library, he was responsible for two major publications on Ontario private presses. ${ }^{82}$

The Publications Committee took on the additional task of preparing sSHRC applications for funding of the Papers/Cahiers. For financial reasons the Committee also supported a recommendation to increase membership fees. Under Kotin's Chairmanship, Council accepted the proposal by the then editor of the Papers/Cahiers, Bruce Whiteman, to issue the journal twice a year, beginning with volume 29, 1991. In 1992 Mary Williamson, Fine Arts Bibliographer at York University Library, assumed the post of Chair of the Publications Committee. Author of many studies in the field of Canadian art, she co-authored with Loren Singer the landmark reference work, Art and Architecture in Canada: A Bibliography and Guide to the Literature to I98I / Art et architecture au Canada: bibliographie et guide de la documetation jusqu'en I98I (Toronto: University of Toronto Press, I99I). In I 992 this work received the Janet Braise Memorial Award for outstanding contribution in the field of Canadian art history.

A major initiative for an important publication project was taken by the President of the Society, Patricia Fleming, in the fall of 1987. She proposed to investigate the possibility of preparing a new edition of Tremaine's Bibliography of Canadian Imprints, I75II 800 , the work being long out of print and many new eighteenthcentury imprints having come to light since its publication in 1952. Eventually, in consultation with the University of Toronto Press, a Supplement to contain items not included or described in the original edition, augmented with new indexes, was decided upon. A ssHRC grant was applied for and received, and the energetic team of Patricia Fleming and Sandra Alston began the project. Many imprints 'not in Tremaine' or 'not seen by Tremaine' have been located over the years, after much travel and research in Canada, the United States and Great Britain. The project is nearing completion, and one would hope that its publication will quickly follow upon the fiftieth anniversary of the Society an appropriate way, indeed, to honour the Society's founder and a great bibliographer. 
At the fall 1987 meeting of Council, the question of вСв3 was reintroduced by Ernie Ingles, who reported that he had been asked to chair a committee of CIBSSSH, which was to propose recommendations for а вСв3. Council gave its approval, and Ingles was authorized to proceed. A Working Group was established at the National Library, with Ingles as Chairman and Fleming representing the Society. Eventually, it was decided that 'there is an identifiable need for a new and revised compilation of a tool such as the всв.' A Project Prospectus was prepared by a National Library staff member, detailing the scope, format, arrangement, methodology, and related aspects. Council supported and authorized the President, Fleming, and Ist Vice-President, Ingles, to seek funding. This was done early in 1989 , with Ingles as coordinator of the project and the Society as its sponsor. Several Society members were named to the Editorial Board. A sSHRC grant was applied for and received, to cover expenses from 1989 to I993. In the spring of I990, a librarian resident in Ottawa, Gordon Adshead, was engaged as researcher and compiler, the National Library providing workspace, access to its collections, databases, reference tools, and other services. After many years of dedicated work, the research was completed in 1993, and the volume published in late 1994 by the University of Toronto Press, thirty-four years after the first edition. ${ }^{83}$ Containing some 7,300 entries, this impressive volume of I, 178 pages is arranged in broad subject categories, reflecting contemporary classification in the fields of knowledge and terminology, with many new areas of research added: women's studies, native studies, urban studies, etc. It is, of course, fully bilingual. The indexes give access through English and French subject headings, authors and titles, providing some 50,000 additional access points. The lengthy introduction contains detailed explanations of criteria for the selection of materials to be included and various definitions. For the first time, the of the copy or copies examined is indicated.

\section{Annual Meetings and Colloquia}

The Constitution and By-laws of the Society stipulate: 'There shall be an Annual Meeting of members in May or June (or some other convenient time), at a time and place determined by Council, in order to receive reports of officers, to elect the officers and members of Council, and to transact the general business of the Society.' Such meetings have been held since 1947, and as the 'founders' had hoped, at various centres across the country, to enable members not 
resident in central Canada to attend the meetings. At these meetings also, speakers have been invited to address members on scholarly topics and aspects of Canadian bibliography. As noted earlier, quite a few officers and members of the Society for many years were closely associated with the Canadian Library Association (also founded in 1946) in various capacities. It is, therefore, not surprising that Annual Meetings were for years held concurrently with the Annual Conferences of CLA (which provided meeting rooms and included the Society's programme with its own). For many years, the minutes of the Annual Meetings regularly included a note of thanks to the long-time CLA Executive Secretary, Elizabeth Homer Morton (I 887-1977). Although the question of meeting with the Learned Societies rather than CLA was debated at Council meetings from time to time, a compromise decision to meet with one or the other group on alternate years was not reached until I 987 , and the first meeting with the Learneds took place at Windsor, Ontario in I988. This step was no doubt favourably viewed by the growing number of academics who had become members of the Society. Since 1986, when the Special Collections Interest Group of CLA was created, joint or concurrent programmes have been set up with this group as well.

In the early years of the Society up to the I970s, Annual Meetings were fairly short, with the 'business meeting' sometimes preceded by a lunch or followed by a dinner, and always with an invited speaker. The topics were, of course, often bibliographical: thus in 1952, in Banff, Neal Harlow, Librarian of the University of British Columbia, spoke on 'Bibliographers in an Age of Science.' In I953, the noted American librarian, Verner Clapp, addressed the members on 'The Role of Bibliographical Societies in National Bibliographical Development.' In I956, H. Pearson Gundy spoke on 'Early Printers and Printing in the Canadas.' Speakers were often invited from a local university or library to present topics related to the literature, history, or bibliography of the region or province where the meeting was being held. In I959, for example, in Edmonton, University of Alberta history professor L.G. Thomas, spoke on 'Churches and Church Records on the History of the Canadian West.' In 196I, at the meeting in St. Andrews-by-the-Sea, Professor Fred Cogswell spoke on 'Nineteenth-Century Poetry in the Maritimes and Problems of Research.' In I963 at Winnipeg, Doris Saunders addressed the Society on 'The Grove Collection in the University of Manitoba: A Tentative Evaluation.' In I966 at Calgary, Bruce Peel spoke on 'The Lure of the West: Immigration 
Pamphlets,' and in I969 at St. John's, Newfoundland Professor Herbert Halpert discussed 'Newfoundland Folklore.'

Towards the end of the I960s, while reviewing the Society's objectives and achievements, Peel prepared a brief in which he advocated a greater participation in bibliographical research related to Canadian studies. He argued for a larger profile of the Society's activity in library and academic circles. In addition, he recommended the establishment of an award to recognize important work in Canadian bibliography. A few years later the latter recommendation was achieved with the creation of the Medal named for founding member and Honorary President Marie Tremaine, who also became the first bibliographer to receive the Medal at the 1970 Annual Meeting in Hamilton. ${ }^{84}$

It was also decided to hold a longer meeting, separately from the Annual Meeting, at which several scholarly papers on Canadian bibliography would be presented. A Committee under the Chairmanship of Hugh Anson-Cartwright, the well-known Toronto antiquarian book dealer, was formed. Financially supported by the Canada Council, a 'Colloquium on I9th Century Canadian Bibliography' was held in November I97 I at the University of Toronto's Massey College, where the initiator and moving spirit behind the meeting, Lochhead, was librarian. The programme attracted over sixty participants. Prominent bibliographers, librarians, historians, and literary scholars were invited as speakers. As the first major meeting of the Society, twenty-five years after its founding, it would perhaps be of interest to describe it in some detail. 85

Responsible for the current as well as the retrospective Canadian bibliography at the National Library of Canada, Jean Lunn addressed the meeting on the projected bibliography to cover the years I867I900, work which had begun in the I950s by Tanghe. In his paper, 'The Historian and I9th Century Bibliography: A Personal Estimate,' Professor J.M.S. Careless discussed Canadian historical writings of the nineteenth century and their importance in shaping modern Canada and national consciousness at a time when literary scholarship was not yet fully developed. Professors John Hare and Jean-Pierre Wallot showed that a literary scholar and a historian can fruitfully work together to produce distinguished bibliographical work. They had recently published their Les imprimés dans le Bas-Canada, I80I-I8Io (Montréal: Les Presses de 1'Université de Montréal, I9671, intended as a continuation of Tremaine's bibliography for Québec imprints. Hare had been responsible for recording and describing the documents included and Wallot for the historical 
notes. They stressed that imprint bibliography was more than just a compilation of titles, but an important contribution to the study of the political, social, and economic history of a period. While discussing the methodology used for the descriptions, following 'Anglo-Saxon' current usage for descriptive bibliography, Hare found that he had to create French terminology for the bibliography because of the lack of awareness of these techniques among scholars in France and francophone Quebec. ${ }^{86}$

The two speakers, however, whose papers probably brought the most 'messages' to the members present, were those of Lochhead and the distinguished American bibliographer, Fredson Bowers, author of many theoretical and methodological works, most notably Principles of Bibliographical Description (Princeton: Princeton University Press, 1949). In his address 'Four Faces of Bibliography,' Bowers began by congratulating the Society on the Colloquium, which 'may become an historical event, a seminal attempt to systematize the field of Canadian bibliography.' He hoped '. . . that with the exercise of that noted Canadian rigour and thoroughness, you can furnish an example to other regions, not least that area that lies on your Southern borders. . . . ${ }^{87}$ Bowers discussed the four principal 'faces' of bibliography (enumerative, descriptive, analytical, textual). The chief thrust of his paper related to his work as editor of nineteenth-century American literary works, and he referred to principles and methods that could also be applied to the study of Canadian authors, many among them deserving a 'full dress' bibliography. With regard to the training required for bibliographical work he called upon the audience to 'do everything in your power to encourage all forms of bibliography as reputable and indeed necessary parts of post-graduate liberal arts training,' not only for librarians and students of literature but also for historians, in fact for all scholars desirous to establish 'pure' texts without which there would be no authoritative editions.

In his paper 'I 9 th Century Canadian Bibliography, to the Land Behind,' Lochhead gave an overview of Canadian bibliographical studies in the nineteenth century. While stating that he had not been asked to prepare a plan of action to promote bibliographical study, Lochhead emphasized that within the Society 'much thought must be given, and strong action taken to acquaint ourselves first, then students, English departments, libraries, and above all, such institutions as the Canada Council with the meaning and implications of that all too-embracing word "Bibliography".' His paper contained a list of observations and questions about the state and 
future of Canadian bibliographical research. We lack a true national bibliography, a chronology and a substantial history of Canadian printing and publishing, and a history of Canadian bibliography. There are very few studies of publishers, printers, or the printing and bookselling industry. What do we know of the type, paper, the presses, the people? Where was paper made and where are the records, not only of the paper mills, but of the type foundries, the manufacturers of presses and of their equipment, and of the printers themselves, their customs and their unions? Referring to bibliographies of the nineteenth-century Canadian writers, he asked: 'Do we have anything that remotely resembles the kind of studies made of American authors?' Lochhead concluded with many recommendations for work and action to be undertaken by the Society and its members, and he urged all to renew their pledge to the aims of the 'founders': 'To promote bibliographical publications; to encourage the preservation and extend the knowledge of printed works and manuscripts, particularly those relating to Canada and to facilitate the exchange of information concerning such rare items.'

Encouraged by the success of the first Colloquium, the Society invited its members to participate in a second colloquium on 'unexplored' aspects of Canadian bibliography. The meeting occurred in November 1973, again at Massey College, with over eighty participants. Speakers had been invited to give papers on 'Canadian Travel Literature' (John Warkentin of York University) and 'Canadian Music Publishing' (Helmut Kallmann, Chief of the Music Division at the National Library). In his paper entitled 'Greeting the Unknowns with a Cheer,' Professor Carl Klinck from Queen's University, editor of the Literary History of Canada, discussed the problems of researching Canadian literature, particularly that of the nineteenth century, hampered by the lack of systematic collecting of these works by institutions. Professor George L. Parker of the Royal Military College of Canada at Kingston presented his pioneer study on 'The British North American Book Trade in the 1840s: The First Crisis.' This colloquium was also notable in bringing to the attention of members present three bibliographers of the younger generation, who in later years published distinguished work in the areas of imprint bibliography, bibliography of Canadian art and architecture, and Canadian carto-bibliography: respectively Patricia Fleming, Mary Williamson and Joan Winearls. Speaking of their work in progress, they presented papers on 'PreConfederation Ontario Book Binding' (Fleming), 'The Subject Index to Illustrations of Canadian Interest' (Williamson), and 'Towards 
a Bibliography of Eighteenth and Nineteenth Century Maps of Ontario' (Winearls).

Some account must be given here of the National Conference on the State of Canadian Bibliography which took place in Vancouver in May $1974 .{ }^{88}$ Sponsored by the University of British Columbia's School of Librarianship and organized by Professor Anne Piternick, it was declared by the National Librarian, Dr. Guy Sylvestre, to have achieved 'the fullest account yet made of bibliographic activity in Canada from its beginnings to the present day, in all disciplines and on an individual as well as on an institutional level.' About two hundred academics, librarians, bibliographers and archivists were invited to participate in discussions. The conference aimed principally at surveying existing and needed enumerative bibliographies on the national and regional level, as well as in a certain number of disciplines in the areas of literature, the arts, the social sciences, science, and technology. Standards and methodology were also on the programme. Although the Society did not sponsor or participate officially at the conference, its members individually had an important role and were very much in evidence. Lochhead as keynote speaker gave an overview of the state of Canadian bibliography. Besides the reports on national bibliographies, regional bibliographies were also examined. These presentations were almost exclusively by members of the Society: British Columbia by Gloria Strathern; the Prairie Provinces by Peel; the Atlantic Provinces by Shirley Elliott; Ontario by Morley. In the papers devoted to subject bibliography, especially in the section entitled 'the arts,' the participation of members of the Society was again prominent: Jacqueline Hunter spoke on 'Fine Arts and Architecture'; Kallman on 'Music'; Richard Landon on 'Canadian Literature in English'; and Hayne on 'Canadian Literature in French'. Landon noted the lack of descriptive bibliographies of Canadian authors' works and underlined the need for libraries to systematically build up their collections of Canadian literature, complemented by authors' papers and manuscripts as well as publishers' records. One of the two major papers on standards and criteria was given by Society member Francess Halpenny, at the time Dean of the Faculty of Library Science, University of Toronto. In her many-faceted overview of Canadian bibliography she emphasized the function of bibliography as an intellectual discipline providing an indispensable basis for the study of any aspect of Canada's past and present.

In his summary of the conference, Roy Stokes, the noted British scholar and bibliographer, then Director of the School of Librarian- 
ship, University of British Columbia, cautioned those present not to rely entirely on national institutions to follow up on the recommendation 'on things which need to be done.' He insisted that 'unless we accept the individual challenge that bibliographical work shall be done and that there is nobody but ourselves to do it.' The sessions generated much lively discussion and also resulted in a great many recommendations, sixty-two in all, on national and regional needs, bibliographical tools in various disciplines that should be undertaken or improved, funding of bibliographical work, and training. A number of the recommendations were addressed to the attention of the Society (the numbering follows that of the published proceedings):

5. That the Bsc be urged to establish such organization and procedures as will result in the indexing of retrospective newspapers and periodicals.

Io. That the Canada Council and the BSc explore jointly methods by which the Council might support bibliographical endeavours and the publication of Canadian bibliographies.

I7. That the BSC or a continuing Conference on Canadian Bibliography maintain a consultative body or register of bibliographers able to give aid to those embarking upon bibliographic or indexing projects.

These 'national' tasks were in part soon assumed by an important agency which was created in response to the major resolution formulated at the close of the conference, asking for the establishment of a National Advisory Council on Bibliographical Services for Canada. The membership of this Council was to be made up of representatives of libraries, academic institutions, research organizations, and societies concerned with bibliographical activities. The principal functions of the Council were proposed as follows: identifying needs and assigning priorities for support of bibliographic activities, defined as identification, description and dissemination of recorded information; making recommendations for bibliographic activities, in part by operating and maintaining a clearing-house for information on all bibliographic projects completed, in progress or planned. In 1975 a Committee of the National Library Advisory Board took on these tasks. Under the somewhat cumbersome designations Committee on Bibliographical Services for Canada (CBSC), from I975 to I980, then Committee on Social Sciences and Humanities Bibliographic and Information Services 
(CsshBis), and from March I98I, Committee on Bibliography and Information Services for the Social Sciences and Humanities (CBISSSH) the Committee met from I975 to I988, and was ably and energetically chaired by several Society members: Margaret Williams, Anne Piternick, Francess G. Halpenny, and Patricia Fleming. It played an important co-ordinating and advisory role by commissioning and undertaking surveys, preparing and issuing in-depth studies and reports, holding workshops, establishing standards for the education and training of bibliographers and indexers, setting criteria for the evaluation of enumerative bibliographies, establishing guidelines for the compilations of bibliographies and lobbying funding agencies. The Society was represented on the Committee from the beginning. Members serving on it were: William F.E. Morley (I 975-8I), Douglas G. Lochhead (I 98I-3), and later Patricia Fleming. Reports on the work of the Committee were made to Council, and were published in the Bulletin.

In 1977 the National Librarian, Dr. Sylvestre, invited the Society to hold a meeting at the Library in the fall of 1978 , as a way of marking the twenty-fifth anniversary of the Library's creation. Chaired by Society's President, David Hayne, Colloquium III was held at the National Library in October 1978 with the theme, 'I 974 Forward: A Review of Developments since the National Conference on the State of Canadian Bibliography.' The two-day programme reviewed progress in bibliographical research, and focused on subjects such as native and multicultural studies, Canadian children's literature, automation and databases, the methodology for enumerative bibliography, and funding and publication of bibliographical research. Greig gave a short overview of bibliographical activity since the Vancouver meeting, which he complemented with a document that he had compiled as the Secretary of the Committee on Bibliographical Services for Canada, entitled Canadian Bibliographical Work in Progress: A Preliminary Subject Inventory (Ottawa: NLAB-CBSC, I978). Updates were presented on national current and retrospective bibliographies. Papers on native language materials before 1900 and on bibliographical access to recent publications on native peoples were given by Joyce Banks of the National Library ('James Constantine Pilling and the Literature of the Native Peoples') and Don Whiteside, author of several important bibliographies in this area ('A Case for the Collection of Fugitive Material about and by the Indians'). 'Early Canadian Children's Books' and 'The National Library's Role in the Bibliographical Access to Canadian Children's Literature' were discussed 
respectively by Judith St. John, Head of the Osborne Collection of Early Children's Books of the Toronto Public Libraries, and Irene Aubrey, the Children's Literature Librarian/Consultant at the National Library. The papers given at the Colloquium were issued in 1979 in a collective volume (in the same format as the Papers) Cahiers edited by Elizabeth Hulse, editor of the journal). ${ }^{89}$

Organized jointly by CBISSSH and the Association for Canadian Studies, an invitational conference, 'Bibliography for Canadian Studies: Present Trends and Future Needs / Bibliographie pour les études canadiennes: situation actuelle et besoins futurs,' was held at Dalhousie University in Halifax in June $198 \mathrm{I} . .^{\circ}$ Considered to be the 'official' second national conference on the state of national bibliography, the papers reviewed developments since 1974. Accounts were also given of the newer disciplines of native, women's and ethnic studies and of progress in computer applications for bibliographical work. Among the highlights of the conference was the report on the work of the Canadian Institute for Historical Microreproductions (founded in 1978) by its first Director, Ernie Ingles. ${ }^{91}$

Longer programmes with substantial papers became the trend of the Society's annual meetings during the I980s and I990s. Programmes were extended from a half-day to a full day, and in more recent years, to two days with up to ten speakers. The longer meetings often had a specific theme or themes: in 1978 at Edmonton, 'Retrospect and Prospects: Developments in Western Bibliography ...' $9^{92}$ in 1979 at Ottawa, primarily bibliographical research, with emphasis on analytical and descriptive bibliography; in r98I at Hamilton, 'Bibliography in the Sciences'; in 1983 at Winnipeg, research and bibliographical projects on the Prairies and publishing in native languages; in 1989 at Edmonton, computer applications, particularly with respect to bibliographical and indexing software; and in 1993 at Hamilton, the 'History of the Book in Canada.'

The most ambitious meeting in the Society's history was held in 1992 at the Learned Societies conference in Charlottetown, P.E.I. In co-operation with the Association for Canadian Studies and the National Library of Canada, the Society organized the 'Third Conference on the State of Canadian Bibliography: Achievements, Challenges, and Opportunities.' The organizing committee was chaired by first Vice-President, Eric Swanick, Legislative Librarian of New Brunswick, who later also was editor-in-chief of the published proceedings. ${ }^{93}$ Experts in many fields, academics, librarians and bibliographers, with an important contingent of francophone 
scholars, had been invited to present syntheses of bibliographical research and publication in the various disciplines within Canadian studies: art and architecture; history; music; literature; geography; communication studies; economics and business; political science; sociology; science and technology; earth sciences; native studies; women's studies; education; multicultural studies; and religion. Much progress was indeed evident in Canadian enumerative bibliography in most areas of the humanities, social sciences and science, and in the publication of retrospective bibliographies, including scholarly imprint bibliographies and catalogues of Canadiana collections in libraries, and of publications of major Canadian publishers. As well, many comprehensive and some descriptive bibliographies of Canadian writers had appeared since 1974, an area where many gaps had been noted and deplored. The considerable upsurge in bibliographical research and publication in the 1980 s can in part be attributed to the funding and support due to the creation of SSHRC in 1978, and particularly to its Canadian Studies Research Tools Programme introduced in 198I. For over ten years this programme provided generous funding to bibliographical projects.

An international dimension was added to the 1992 conference by the presence of three special guests invited from Great Britain, the United States, and France. In his paper 'Bibliography in the Computer Age,' Robin Alston, founder of the Eighteenth-Century Short-Title Catalogue (ESTC) and since 1990, Director of the Library School at University College, London, spoke on the development of computer technology and its impact on the production of books, on libraries, bibliography, and ultimately, on the whole world of knowledge. He concluded by saying: 'That we are living at a time of great changes in the ways which knowledge is produced, disseminated and acquired, no one can doubt: whether they are wholly beneficial for the commonwealth of learning is not quite so clear.' In his exposé, 'Enumerative Bibliography and the Physical Book,' Thomas G. Tanselle cautioned bibliographers to reconsider the distinctions usually made between enumerative bibliographies (as referring to the intellectual contents of the works listed) and descriptive bibliography (as dealing with books as material objects). Robert Estivals, the founder and president of the Sociéte de bibliologie et de schématisation, as well as of the Association internationale de bibliologie, gave an overview of the development of the concept of bibliology and the manifold components of this vast field of knowledge (among others all aspects of bibliography, histoire du livre, etc.). ${ }^{94}$ A proponent of the fostering of inter- 
national understanding of the theoretical thought and methodology developed by the various 'national' schools of bibliography, he expressed the hope that his Association internationale de bibliologie would be a forum where information would be exchanged and shared and comparative studies would flourish 'pour éviter la désinformation et permettre le progrès.'

At the close of the 1992 conference I04 resolutions were formulated. Several among them were addressed to the attention of the Society. Some examples are: nos. 4 and 5 underlined the importance of the education of bibliographers, particularlyin analytical, textual, historical and descriptive bibliography, in faculties of library science and other graduate departments; and that the 'BSC/SBC, in conjunction with Faculties of Library Science, be asked to co-ordinate the continuing education programs in bibliography for practising librarians and other professionals. ${ }^{95}$ Resolution no. 13 recommended 'That the National Eibrary of Canada develop a program for the study of the book in Canada, working with the BSC/sBC and other libraries and institutions to encourage research and publication. ${ }^{196}$ In his concluding remarks at the 1992 conference, Richard Landon noted that 'the new academic disciplines which encompass the history of the book, or "histoire du livre" ... provide opportunities to expand the scope and the significance of bibliographical study.'

\section{Conclusion}

Recognizing the vital role of individual bibliographers, the Society has honored outstanding acievements in this field with the Marie Tremaine Medal. Since I 970 sixteen Canadian scholars have been awarded the Medal for contributing comprehensive and definitive bibliographies in various fields of Canadian studies: Canadian history and literature, retrospective and imprint bibliographies of Canada and its regions from British Columbia to Newfoundland, cultural and social history, urban studies, government publications, and carto-bibliography. The Medal winners are: Marie Tremaine (1970); John Hare and Jean-Pierre Wallot (I973); Bruce Braden Peel (1975); William F.E. Morley (1977); Reginald Eyre Watters (1979); Olga Bernice Bishop (I 981); Alan F.J. Artibise (I983); Douglas Grant Lochhead (I985); Agnes Cecilia O'Dea (I987); Sandra Alston (I988); Gloria M. Strathern (I989); Claude Galarneau (1990); Patricia Lockhart Fleming (I992); Joan Winearls (I993); Paul Aubin (I994).

The Society has encouraged participation in its activities by bibliographers of the younger generation, graduates of academic faculties or schools of library science in Canada and abroad. They 
have been awarded fellowships and have been invited to present the results of their research at Annual Meetings and to publish their work in the Papiers/Cahiers. In its first fifty years the Society and its members contributed considerably to developments in many areas of Canadian bibliography. The Society can now look ahead with confidence to the 'challenges and opportunities' of the its next half century. 
APPENDIX: Presidents of the Bibliographical Society of Canada / La Société bibliographique du Canada

$\begin{array}{ll}\text { HONORARY } & \text { PRESIDENTS: } \\ \text { I948-6I } & \text { Lorne Pierce } \\ \text { I964-84 } & \text { Marie Tremaine } \\ \text { PRESIDENTS: } & \\ \text { I946-8 } & \text { Victor Morin } \\ \text { I948-50 } & \text { Fred Landon } \\ \text { I950-2 } & \text { Rev. A.M. Morisset, o.m.i. } \\ \text { I952-4 } & \text { W. Kaye Lamb } \\ \text { I954-5 } & \text { Louis Blake Duff } \\ \text { I955-6 } & \text { Gérard Malchelosse } \\ \text { I956-8 } & \text { Florence B. Murray } \\ \text { I958-60 } & \text { Raymond Tanghe } \\ \text { I960-2 } & \text { Vernon Ross } \\ \text { I962-4 } & \text { Willard E. Ireland } \\ \text { I964-6 } & \text { Marion E. Brown } \\ \text { I966-8 } & \text { Martha Shepard } \\ \text { I968-70 } & \text { Inglis F. Bell } \\ \text { I970-2 } & \text { Bruce Peel } \\ \text { I972-4 } & \text { Douglas G. Lochhead } \\ \text { I976-8 } & \text { Olga B. Bishop } \\ \text { I978-80 } & \text { David M. Hayne } \\ \text { I980-2 } & \text { Gloria M. Strathern } \\ \text { I982-4 } & \text { Liana Van der Bellen } \\ \text { I884-6 } & \text { Desmond G. Neill } \\ \text { I986-9 } & \text { Patricia Fleming } \\ \text { I989-9I } & \text { Ernest (Ernie) Ingles } \\ \text { I99I-3 } & \text { Sandra Alston } \\ \text { I993-5 } & \text { Eric L. Swanick } \\ \text { I995- } & \text { Thomas B. Vincent } \\ \end{array}$




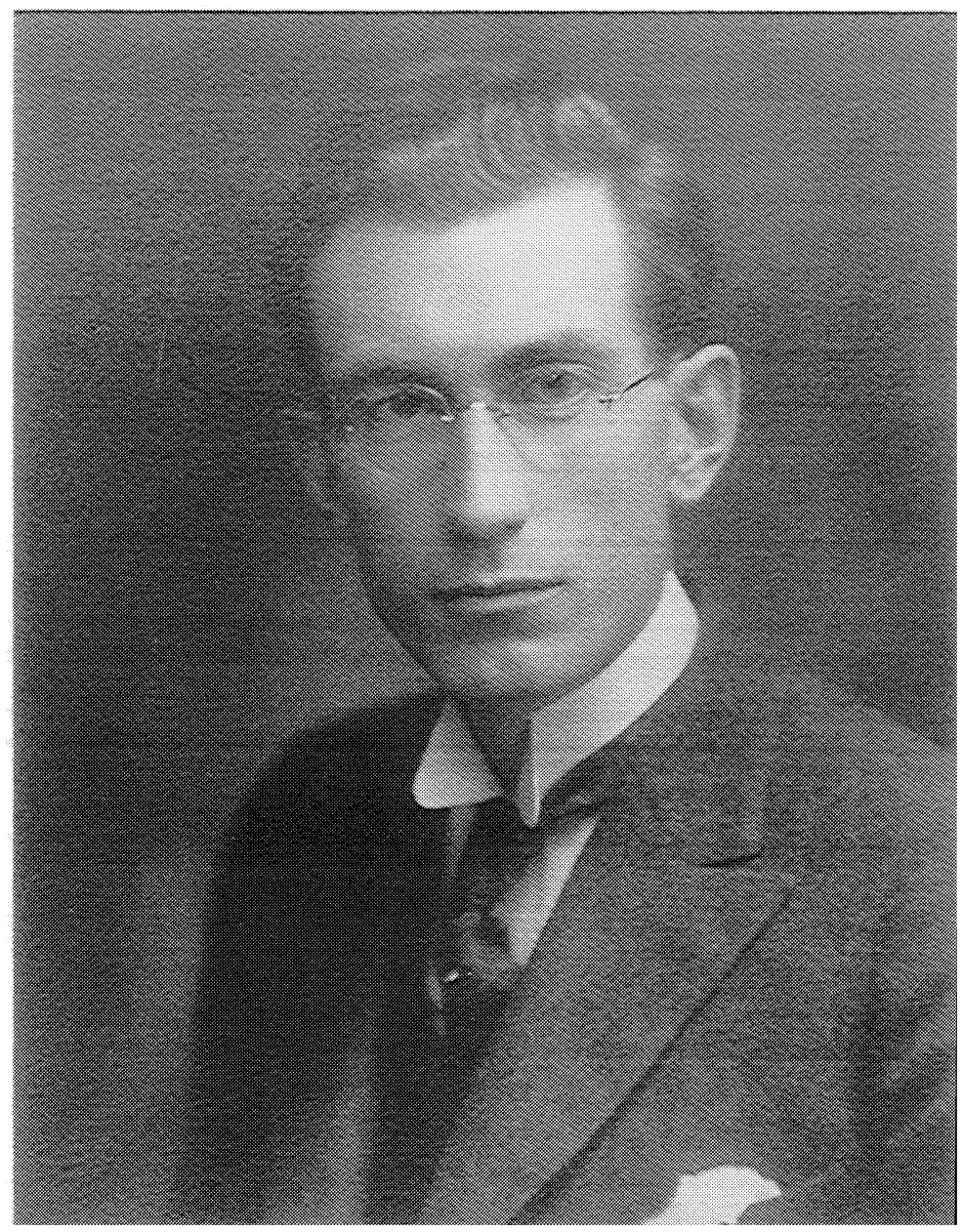

I. Lorne Pierce, I890-I96I

Courtesy of the Queen's University Archives. 


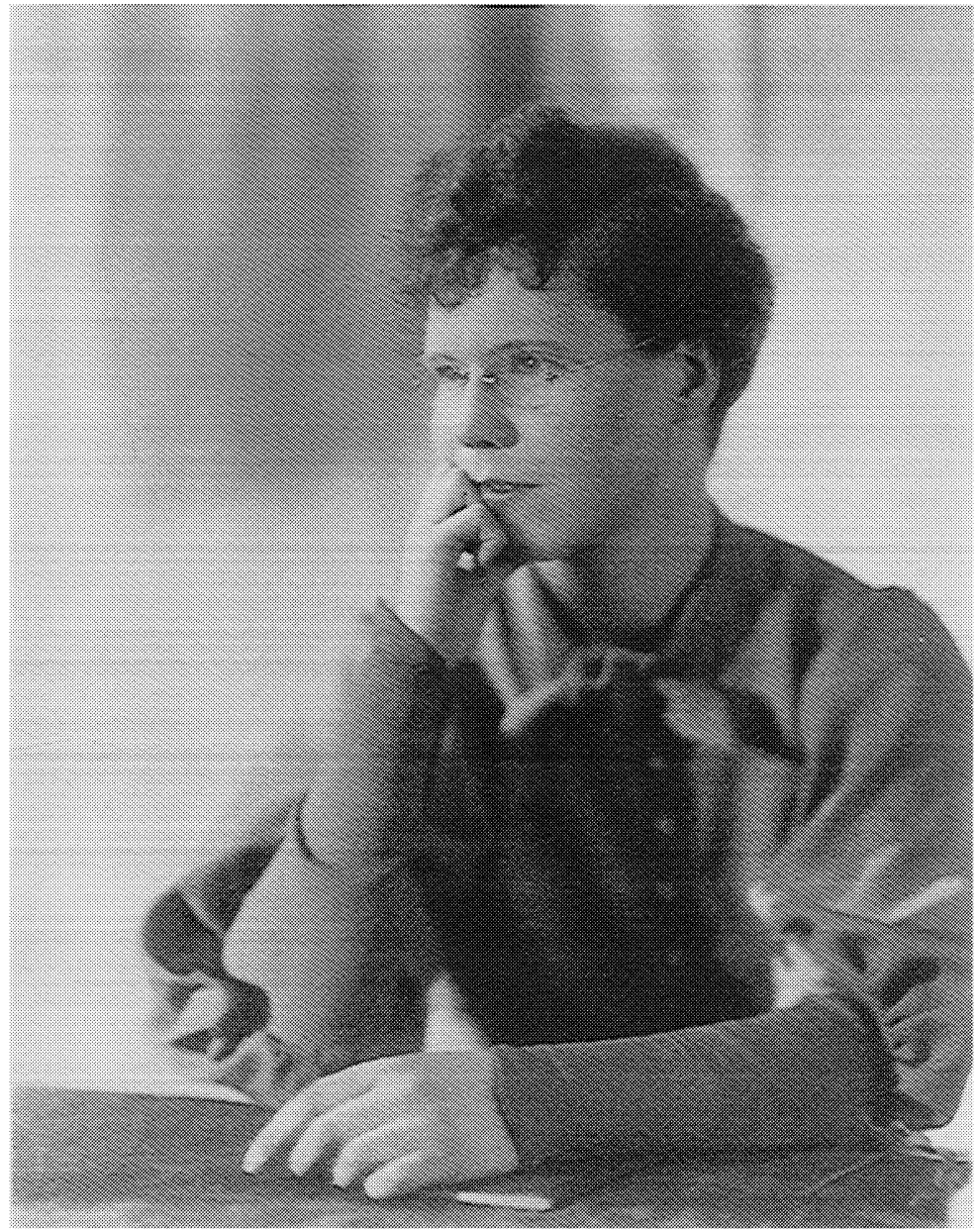

2. Marie Tremaine, I $902-84$ Courtesy of the Queen's University Archives. 
I58 Papers of the Bibliographical Society of Canada $34 / 2$

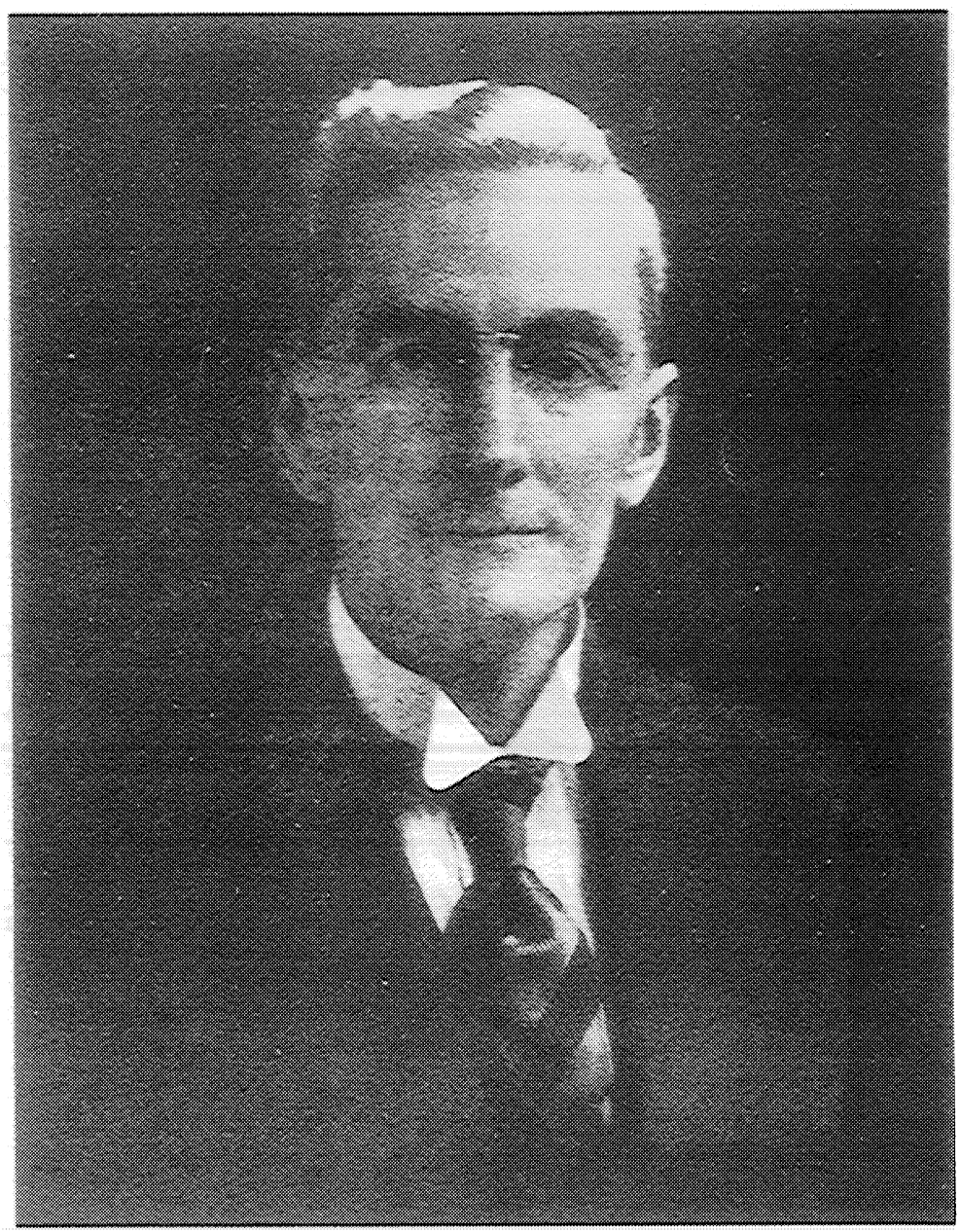

3. Ernest Cockburn Kyte, I 876-197I

Courtesy of the Queen's University Archives. 
RÉSUME

La Société bibliographique du Canada fut fondée en mai 1946, quelques semaines à peine avant la Canadian Library Association/Association canadienne des bibliothèques. On doit l'idée de la création d'une association groupant ceux qui oeuvrent dans le domaine de la bibliographie au Canada à trois personnalités remarquables que la Société honore comme ses fondateurs: Lorne Pierce (1890-196I), Rédacteur-en-chef de la Ryerson Press de Toronto, une des plus anciennes et importantes maisons d'édition au Canada; Ernest Cockburn Kyte (I876-I97I), Directeur de la bibliothèque de l'Université Queen's à Kingston; et Marie Tremaine (I902-1984), doyenne des bibliographes canadiens, auteur de l'ouvrage fondamental sur les imprimés canadiens $d u \mathrm{xvIr}^{\mathrm{e}}$ siècle A Bibliography of Canadian Imprints, 175 I-I800, publié en I952.

$\grave{A}$ une réunion, convoquée pour le 20 mai 1946 à Toronto furent présents à la fondation officielle de la Société quatorze personnalités $d u$ monde des livres (bibliographes, bibliophiles, libraires), des bibliothèques et quelques universitaires, parmi lesquels furent plusieurs francophones et membres de la Société royale du Canada. On discuta des objectifs et de la constitution de la future société, de son organisation, des projets de recherches et des publications, des réunions, du recrutement des membres, etc. Les projets bibliographiques ambitieux, les suggestions touchant la collection et la préservation des canadiana anciens témoignent du fait que le Canada ne possédait pas encore une Bibliothèque nationale (fondée en 1953). A la première réunion annuelle de la SBC tenue en juin 1947, l'érudit notaire de Montréal, Victor Morin, fut élu président et Marie Tremaine, secrétaire. Elle quitta bientôt le Canada pour se consacrer à la rédaction de la Arctic Bibliography à Washington. Tremaine continua cependant à s'intéresser à la sBC jusqu'à la fin de sa vie. Elle fut élue présidente honoraire en I965. Parmi les membres du premier conseil de la SBC fut $W$. Kaye Lamb, Archiviste national, qui devint Bibliothécaire national en 1953 , et qui appuya pendant tout le long de son mandat les activités de la Société. La constitution fut adoptée à la première réunion annuelle. Elle énumerait les buts ou objectifs de la sBC qui n'ont pas changé de façon marquante au cours de son histoire et sont cités ici tel qu'ils paraissent dans la constitution revisée en I98I:

I. De favoriser l'étude de la bibliographie et d'encourager la publication d'ouvrages bibliographiques (notes, articles, éditions, 
livres, etc.) en particulier ceux qui se rapportent au Canada.

2. D'encourager la conservation des ouvrages imprimés et des manuscrits en particulier ceux qui se rapportent au Canada, et de les faire mieux connaître.

3. De faciliter l'échange de renseignements sur lesdits ouvrages et manuscrits.

La Société est administrée par un exécutif et un conseil (dont le nombre a été augmenté de six à neuf membres, avec un mandat de trois ans) qui sont tous des bénévoles, les revenus modestes de la Société dérivés des cotisations ne permettant pas d'engager du personnel ni de louer des locaux permanents. Il faut souligner l'importante contribution de la part de Mme J.C. (Esther) Jacobsen qui a assuré une période de stabilité à la sBC comme organisation pendant son mandat comme secrétaire-trésorière qui a duré presque 25 ans, de I95s à I 979.

Dès le début, la Société a attaché une grande importance à son programme de publication dont le but était pendant longtemps de rechercher, préserver et faire connaître les publications canadiennes anciennes. Malgré ses difficultés financières, la sBC a réussi à publier des monographies et des périodiques. Pierce, membre fondateur et président honoraire en 1948, apporta son appui au comité des publications par ses conseils et souvent par son aide financière. Les premières monographies étaient de minces brochures, d'abord des réimpressions, puis des facsimilés des imprimés canadiens des $\mathrm{xVIII}^{\mathrm{e}}$ et $\mathrm{xIx}^{\mathrm{e}}$ siècles choisis par les membres. Le but du projet était la préservation et la distribution à prix modique des canadiana 'introuvables' publiés en anglais ou en français provenant de toutes les régions du pays. Quatre fascicules furent publiés dans la collection des réimpressions (Reprint Series, I-4, I949-1950) et neuf dans la collection des fac-similés (Facsimile Series, I-9, I95 I-1975). Il s'agissait d'un véritable travail de coopération: les exemplaires originaux furent fournis par les institutions, les membres rédigèrent des notes historiques sur les brochures. Ces notes constituent une contribution importante à l'histoire de l'édition et de l'imprimerie au pays. Voici quelques titres: Thoughts on the Education of Youth de Richard Cockrel. Newark, I795 (I949); Représentations par le Corps de Grands Jurés. Québec, I765 (1949); Aux citoyens et habitants des villes et des campagnes de la Province de Québec. Québec, 1785 (I95I); Sawney's Letters, par James Anderson, Barkerville, I 868 (I950); Cree Syllabic Hymn Book, par James Evans. Norway House, I 84 I (I954). 
La première monographie originale à être publiée par la Société était Early Printers and Printing in the Canadas, par H. Pearson Gundy (1957).

Un des projets de publication les plus ambitieux, réalisée en étroite collaboration avec la Bibliothèque nationale, fut la Bibliographie des bibliographies canadiennes. Les membres à travers le pays contribuèrent des bibliographies de leurs régions, la rédaction étant assumée par Raymond Tanghe, Bibliothécaire adjoint à la Bibliothèque nationale. Le volume bilingue, contenant 1,665 notices bibliographiques parut en 1960. Trois suppléments furent publiés entre 1962 et 1966. Une deuxième édition comportant 2,323 notices fut publiée en 1972, sous la direction de Douglas Lochhead, alors bibliothécaire au Massey College de l'Université de Toronto. L'index très détaillé fut compilé par Peter Greig, qui fut plus tard nommé rédacteur de la troisième édition de la bibliographie. Il travailla pendant plusieurs années à la compilation qui fut achevée par Gordon Adshead. La troisième édition fut publiée sous la direction de Ernie Ingles en 1994, un volume imposant contenant plus de 7,000 notices, un témoignage du developpement de la bibliographie systématique au Canada depuis la publication de la première édition.

Les années 1970 verront la parution de quelques monographies importantes: A Bibliographical Study of Major John Richardson, par William F.E. Morley (1973); An Index to the Canadian Monthly and National Review . . par Marilyn Flitton (1976); Specimen of Printing Types and Ornaments in Use at the Printing Office of Lovell \& Gibson ... (1975). À part des monographies, la SBC a aussi publié un certain nombre de périodiques: neuf numéros d'un Bulletin (ancienne série) paraissaient de 1949 à 1952, un Bulletin de nouvelles (Newsletter) suivit entre I95s et 1962 et Le Bulletin (nouvelle série) vit le jour en 1973 et parait depuis deux fois l'an. Ces bulletins contenaient des nouvelles susceptibles d'intéresser les membres: des documents 'officiels' de la Société comme les procèsverbaux des réunions; des notices des publications de la Société et de ses membres, etc. Afin de pouvoir publier des textes des communications données aux réunions ainsi que des articles, la décision fut prise en 1962 de cesser la publication du Bulletin de nouvelles et de publier à sa place une revue annuelle sous le titre de Cahiers de la Société bibliographique du Canada. Depuis I99I, les Cahiers sont publiés deux fois l'an.

Dès 1947, la Société a regulièrement organisé des réunions annuelles pour élir les membres de l'éxécutif et du conseil, présenter des 
rapports et discuter des questions touchant tous les aspects de la bibliographie canadienne. Jusqu'en 1987, la SBC tenait ses réunions en même temps et au même endroit que l'Association canadienne des bibliothèques, la grande majorité de ses membres étant bibliothécaires. Depuis I 988 la SBC se réunit tout à tour avec l'Association canadienne des bibliothèques et les Sociétés Savantes. Depuis la création du groupe des Collections spéciales de le Canadian Library Association, la SBC a souvent tenu ses réunions avec ce groupe. De 1947 à 1977 les programmes des réunions furent assez brefs: la réunion annuelle proprement dite suivie d'une causerie par un conférencier invité. Depuis 1978 les réunions ont une durée d'une ou deux journées avec de quatre à dix conférenciers. Les programmes présentent souvent un thème comme par exemple: développement de la bibliographie dans l'ouest du pays; bibliographie matérielle; bibliographie dans le domaine des sciences; la bibliographie et l'automation; histoire du livre au Canada, etc. La SBC a aussi tenu trois colloques en 1971, I973 et 1978. Le premier colloque était consacré à la bibliographie canadienne du $\mathrm{xIx}^{\mathrm{e}}$ siècle, le deuxième traitait de divers aspects de la recherche bibliographique au Canada. Les communications présentées aux deux premiers colloques ont paru dans les volumes $\mathbf{x}$ et XII des Cahiers. Le troisième colloque, intitulé 'I 974 Forward', passait en revue les principales étapes de la recherche bibliographique au Canada depuis l'importante Conférence nationale sur l'état de la bibliographie Canadienne tenue à Vancouver en mai 1974 en présence de quelques 200 bibliothécaires, bibliographes, universitaires et archivistes. Les compte-rendus $d u \mathrm{II}^{\mathrm{e}}$ colloque furent publiés en 1979. La Société fut l'un des organismes representés au sein du Comité des services bibliographiques pour le Canada du Conseil consultatif de la Bibliothèque nationale créé à la suite d'une recommendation émise au congrès de 1974. Ce comité, entre 1975 et I988, a enquêté sur les besoins bibliographiques au Canada afin d'établir des priorités; a formulé des recommendations aux organismes qui accordent des subventions aux chercheurs; a établi des critères et des normes de compilation bibliographiques; organisé des ateliers d'indexation, etc. Des rapports des activités de ce comité furent publiés dans le Bulletin de la SBC.

Après un deuxième congrès national tenu en 1981 dans lequel la Société n'était pas impliquée, elle organise en 1992 à Charlottetown, avec le concours de l'Association des études canadiennes et la Bibliothèque nationale du Canada une 'Troisième conférence sur la bibliographie canadienne: réalisations, défis, perspectives.' 
Des experts dans diverses disciplines des sciences, des sciences sociales et humaines ont présenté des synthèses. On pouvait constater des progrès considérables dans la bibliographie systématique dans tous les domaines des connaissances incluant la bibliographie littéraire et la bibliographie des oeuvres d'écrivains canadiens dont on avait constaté les lacunes au congrès de 1974. Trois conférenciers importants venus d'Angleterre, de la France et des États Unis ont ajouté une dimension internationale à ce congrès: Robin Alston, le fondateur du ESTC (English Short Title Catalogue - Récension des imprimés anglais et en langue anglaise du $\mathrm{xvIII}^{\mathrm{e}}$ siècle) Robert Estivals, fondateur de la Société de bibliologie; et Thomas Tanselle grand spécialiste américain de la bibliographie matérielle et textuelle. Le compte-rendu de ce congrès fut publié par la Société en 1994. Plusieurs resolutions de ce congrès furent addressées à l'attention de la sBC dont au moins une a déjà été réalisée, celle qui recommendait que la $\mathrm{SBC}$, de concert avec les écoles de bibliothéconomie, coordonne des programmes d'éducation permanente en bibliographie pour les bibliothécaires et d'autres professionnels. Dès 1993, la Société, en collaboration avec la Bibliothèque nationale du Canada a mis sur pied un Institut de bibliographie qui a organisé deux cours d'été d'une semaine sur la bibliographie matérielle en 1993 et 1995.

Pour honorer les bibliographes, la SBC a créé en 1970 la Médaille Marie-Tremaine attribuée pour service exceptionnel dans le domaine de la bibliographie canadienne. Depuis I 970 seize bibliographes ont reçu la médaille pour leur oeuvre importante dans les divers domaines de la bibliographie canadienne: histoire et littérature; bibliographie rétrospective des régions du Canada de la Colombie britannique à Terre-Neuve; bibliographie retrospective des imprimés anciens canadiens; histoire culturelle et sociale; publications officielles; études urbaines; cartobibliographie; Marie Tremaine (1970); John Hare et Jean-Pierre Wallot (1973); Bruce Braden Peel (1975); William F.E. Morley (1977); Reginald Eyre Watters (1979); Olga Bernice Bishop (1981); Alan F.J. Artibise (1983); Douglas Grant Lochhead (1985); Agnes Cecilia O’Dea (1987); Sandra Alston (1988); Gloria Strathern (1989); Claude Galarneau (1990); Patricia Lockhart Fleming (1992); Joan Winearls (1993); Paul Aubin (1994). Tandis que la médaille Marie-Tremaine est destinée à honorer les bibliographes chevronnés, la Société a aussi encouragé ceux qui étaient à leurs débuts. Elle a donc invité la participation de la jeune génération des bibliographes en les incitant à donner des communications et à soumettre des articles 
pour être publiés dans les Cahiers. En plus elle leur offre deux bourses d'études: la bourse Tremaine et la bourse Bernard Amtmann.

Ayant consacré beaucoup de temps et d'énergie à enquêter sur la bibliographie canadienne en organisant des colloques et des congrès et ayant recensé les bibliographies canadiennes dans la magistrale troisième édition de la Bibliographie des bibliographies canadiennes, la SBC semble être prête à consacrer ses efforts à la recherche dans le domaine de l'histoire du livre au Canada. 
NOTES

I Although well known to its members, the work of the Society over the years has not received much international recognition. Savina A. Roxas, in her article 'Bibliographical Societies, Development of' in The Encyclopedia of Library and Information Science, vol. 2 (New York: Marcel Dekker, 1969), 386, briefly mentions the founding of the Bibliographical Society of Canada in 1946, while entire articles treat the more 'famous' societies in some detail. The Society receives some attention in a recent French reference work, Robert Estival's Les sciences de l'écrit: encyclopédie internationale de bibliologie (Paris: Retz, 1993). A succinct but informative article under the title 'Canada: la bibliologie au Canada (écrits en langue anglaise),' summarizes the 'bibliological' activities in this country since the founding of the Society. It is signed by the long-time member, Dr. David Hayne. One has to note the absence of any references to bibliographical work in Canada in general or of the Society in particular in articles or monographs celebrating 'anniversaries' of other societies in this field. For example, the impressive volume The Book Encompassed: Studies in Twentieth-Century Bibliography (Cambridge: Cambridge University Press, 1992), a collection of essays by international scholars in honour of the centennial of the Bibliographical Society, devotes a chapter to bibliography in two other Commonwealth countries, Australia and New Zealand, but not a word to Canada.

2 This information is contained in a letter of Marie Tremaine to Marie-Claire Daveluy, Bibliothèque Municipale in Montréal, 3 August 1943. National Library of Canada, Special Collections. Fonds Marie-Claire Daveluy (1880-1968). All of the early correspondence (circular letters sent by Tremaine to potential members of a Bibliographical Society of Canada) and documents attached to them, I943 to 1946 are from this source.

3 In his note on Pierce, entitled 'Lorne Pierce: fondateur de la Société bibliographique du Canada,' BSC Newsletter 3, no. 2 (December 1959): 2, Raymond Tanghe states: 'Nos archives contiennent des lettres datant de 1928 qui témoignent que, dès cette époque Lorne Pierce s'occupait de la formation d'une société de bibliographie.'

4 There is no major account of Pierce's life and work yet published. However, Sandra Campbell, a member of the University of Ottawa's Department of English, author of a recent article 'Nationalism, Morality and Gender: Lorne Pierce and the Canadian Literary Canon, 1920-60,' Papers of the Bibliographical Society of Canada 32, no. 2 (Fall 1994): 135-60, states that she is working on a biography of Pierce. Earlier sources are: C.H. Dickinson, Lorne Pierce: A Profile (Toronto: The Ryerson Press, 1965). This small seventy-nine page book was distributed free to members of the Society through the generosity of the son and daughter of Pierce (Mr. Bruce Pierce and Mrs. J.D. Robinson), with a note dated September 1970 inserted into all copies recalling that 'May of next year will mark the passage of a quarter century since Dr. Pierce presided over a meeting of like-minded persons the result of which was the formation of the Bibliographical Society of Canada.' The Society dedicated a whole issue of its News- 
letter to Dr. Pierce, entitled 'A special issue in honour of Dr. Lorne Pierce, Honorary President of the Bibliographical Society of Canada, on the occasion of his retirement as Editor of the Ryerson Press. . . ' BSC Newsletter 3, no. 2 (December 1959): I-8.

5 Pierce, An Editor's Creed (Toronto: The Ryerson Press, 1960). When Pierce included volumes in French on French-Canadian writers in Ryerson's The Makers of Canadian Literature Series, he invited Victor Morin /as Pierce Fellow of the Royal Society of Canada) to be Associate Editor of the series.

6 W.F.E. Morley, ed., Ernest Cockburn Kyte: A Tribute, Douglas Library Occasional Papers, no. 2 (Kingston, Ont.: Douglas Library, Queen's University, 1970). Includes contributions by H. Pearson Gundy, Kyte's successor as Librarian at Queen's with excerpts of Kyte's letters to Gundy written between 1947 and 1968. Evelyn Fudge compiled 'A Selected List of the Writings of E. Cockburn Kyte.' Other contributions are by Anne MacDermaid and W.F.E. Morley. Two short stories and poems by Kyte are also included.

7 See the obituary by Morley, 'Ernest Cockburn Kyte (1 876-1971): Scholar Librarian,' Papers of the Bibliographical Society of Canada 9 (1970): I I.

8 For biographical notes, see 'Marie Tremaine, 1902-1984 A Tribute,' Papers of the Bibliographical Society of Canada 23 (1984): 12-29.

9 It is fitting indeed that on the fiftieth anniversary of the Society, two Canadian bibliographers of another generation, having tracked down many 'not in Tremaine' and 'not seen by Tremaine' items, are preparing a supplement to this remarkable work: Patricia Fleming /who like Tremaine pursued graduate studies at the University of London, Ph.D., I980) and Sandra Alston, both holders of the Tremaine Medal (established by the Society in 1970).

Io Early Printing in Canada (Toronto: Golden Dog Press, 1934). Reprinted in Papers of the Bibliographical Society of Canada 23 (1984): 32-9. Tremaine edited The Canadian Book of Printing: How Printing Came to Canada and the Story of Graphic Arts (Toronto: Toronto Public Libraries and 50oth Anniversary Committee, r950). 'Canadian-American Relations in Colonial Printing,' College and Research Libraries 7 (January 1946): 27-33. In I95 I, she contributed an article 'A Half-Century of Canadian Life and Print, 175 I-1800' to Essays Honoring Lawrence C. Wroth (Portland, Maine: 1951), 371-90. Reprinted in Papers of the Bibliographical Society of Canada 23 (I984): 40-55.

I I This proved to be somewhat optimistic. The membership fee finally decided upon was $\$ 2.00$ for individuals, and even with unrestricted membership recruitment, it took many years for the bank balance to reach the $\$ 1,000.00$ mark.

I2 Thus from the first, the idea of meeting with the Learned Societies was considered. However, early in the Society's history, a tradition was established of holding the Annual Meeting of the Society at the time and the place of the annual conference of the Canadian Library Association (also founded in 1946). Many of the members of the Society were librarians, and the early Executive and Council were composed of people closely associated with the CLA.

I 3 This very ambitious proposal does not appear again in any later Society documents. With the lack of permanent quarters, and the chronic shortage of funds, 
it would not have been a feasible undertaking at any time in the Society's history.

I4 The National Library of Canada Act was passed in Parliament in 1952, and came into effect on I January I953. For the long history preceding the creation of the Library, see F. Dolores Donnelly's The National Library of Canada: A Historical Analysis of the Forces which Contributed to its Establishment and to the Identification of Its Role and Responsibilities (Ottawa: Canadian Library Association, 1973). A government agency which began to execute some of the National Library's tasks in 1950, and was later incorporated into this institution, was the Canadian Bibliographic Centre, with the task to compile a Union Catalogue of the holdings of the major libraries in Canada and to begin publishing a national (current) bibliography Canadiana, listing titles of Canadian origin, authorship or interest.

I5 The aims of сінм are discussed in E.B. Ingles's 'The Canadian Institute for Historical Microreproductions: Objectives - Methodologies,' Canadian Issues 4 (1982): 137-46.

I6 First published in Transactions of the Royal Society of Canada 5 I Ser. III (June 1957) Section 2: I-II. Reprinted in Papers of the Bibliographical Society of Canada 24 (1985): 73-85.

17 'Colloquium on Nineteenth-Century Canadian Bibliography, Papers of the Bibliographical Society of Canada 1o (I97 I): 3 I-84. The Bibliographical Society of Canada, Colloquium III / La Société bibliographique du Canada IIIè colloque. National Library of Canada, Ottawa, 19-21 October, 1978 / Bibliothèque nationale du Canada, Ottawa, le I9-2 I octobre, I978. (Toronto: Bibliographical Society of Canada/Société bibliographique du Canada, 1979).

I 8 National Conference on the State of Canadian Bibliography, Vancouver, May 22-24, 1974. Proceedings. Anne B. Piternick, ed. (Ottawa: National Library of Canada, I977). A French language edition was published separately. Bibliography for Canadian Studies: Present Trends and Future Needs / Bibliographie pour les études canadiennes: situation actuelle et besoins futurs. Proceedings of a Conference Held at Dalhousie University, Halifax, N.S. on June I \& 2, I98 I. Anne B. Piternick, ed. Canadian Issues 4 (1982): xii, I-193. Third National Conference on the State of Canadian Bibliography: Achievements, Challenges and Opportunities, Charlottetown, P.E.I., May 3I-June I, 1992 / Troisième conférence nationale sur la bibliographie canadienne: réalisations, défis, perspectives, Charlottetown, PE.I., 3 I mai-I juin, 1992. Proceedings/Compte rendu. Editor-in-Chief/Rédacteur: Eric L. Swanick (Toronto: Bibliographical Society of Canada / Société bibliographique du Canada, 1994). xxi, 467 pp.

I9 One might speculate that she was replacing Dr. Freda Waldon, the Head Librarian and well known for her bibliographical research. Dr. Waldon was, no doubt, fully occupied at the time as a founder (and first President) of the Canadian Library Association, which held its founding meeting in June 1946 on the McMaster University campus in Hamilton.

20 Dora Hood's memoirs, under the title The Side Door: Twenty-Six Years in my Book Room (Toronto: The Ryerson Press, 1958), are one of the few personal accounts by a Canadian book dealer that provide entertaining and informative 
insights into her pursuit of rare Canadiana and her encounters with collectors, with many references to books handled by her.

2 I Morin's daughter, Renée, published a biography of her father, Un bourgeois d'une époque révolue: Victor Morin, notaire, I865-1960 (Montréal: Editions du Jour, 1967$)$.

22 Also to be found in the Fonds Marie-Claire Daveluy, National Library of Canada. Special Collections.

23 In 1947 Tremaine accepted a position in Washington to edit the Arctic Bibliography for the Arctic Institute of North America, and was succeeded by Donalda Putnam as Secretary. She continued to follow the activities of the Society with interest, often participating at meetings and colloquia. She was named Honorary President in 1965 .

24 Terry Cook, 'W. Kaye Lamb, Archives and Libraries,' Archivaria no. I5 (Winter I982/83): 2. The whole issue, a festschrift in his honour, is dedicated to Dr. Lamb's career and writings.

25 Ducharme also maintained an extensive card file (described in one of his catalogues as containing some 400,000 items) of bibliographical and historical notes, which was continued by his successor, Gérard Malchelosse. This file, known as the 'Fichier Ducharme-Malchelosse,' has been consulted by bibliographers either in its original (at Laval University and Archives du Québec) or in microform.

26 Morin's Chairman's and Debater's Guide to Deliberative Assemblies (in French, Procédure des assemblées déliberantes) has been used for proceedings by the Society. In 198I, Tremaine presented a signed copy of the first Frenchlanguage edition (I939) to the Society.

27 Bsc Bulletin no. I (May 1949): I.

28 The constitution, as published in Papers/Cahiers I (1962): 3-12, is almost identical to the earlier version presented at the 1947 Annual Meeting. A revised constitution was voted on at the r98 I Annual Meeting and published in Papers/ Cahiers 20(I98I): I-20. Amendments have been passed in recent years, reflecting changes in functions of officers. A newly revised constitution was presented to the members at the 1996 Annual Meeting.

29 In 1969, some members expressed the need to involve the Society in examining the 'present level and future needs' of indexing in Canada. An Indexing Committee was formed with Peter Greig as Chairman. The Committee was active for several years, publishing four issues of a Newsletter between 1970 and 1973 . It evolved into the Indexing and Abstracting Society of Canada in 1977. The former Chairman of the Committee was named Indexer to the Society. The holder of this office has been responsible for indexing the Papers/Cahiers, and eventually other serial publications and documents of the Society, such as the Bulletin, Annual and Council meeting minutes, etc. On this topic, see also Greig's article 'Indexes, Indexing, and the Bibliographical Society of Canada,' Papers/Cahiers I5 (1970): 62-8.

30 For CBSs and later CBISSSH Committee on Bibliography and Information Services for the Social Sciences and Humanities, see pp. 147-8. 
3 I After the inauguration of the Eighteenth-Century Short-Title Catalogue (ESTC) project, the National Library of Canada called an invitational meeting of rare book librarians in November 1980 at which Robin Alston, the founder and Editor of ESTC, and Henry Snyder, Director of its North American office, were present. At the meeting, a Canadian Advisory Committee was created, with Richard Landon, of the Thomas Fisher Rare Book Library of the University of Toronto, as Chairman. For many years, Landon attended Council meetings and reported on ESTC's progress and also on Canadian participation in submitting pertinent materials to the project. For an assessment of the project, see Stephen Francom,'Coverage of Canadian Imprints in ESTC on CD-ROM (1992),' Papers/Cahiers 33, no.I (Spring I995): 7-30.

32 In March 1987, the Council met in Sackville, New Brunswick, at the time of the Anchorage Series Symposium on 'Printing and Publishing in Atlantic Canada, 175 I-1987,' held at Mount Allison University's Centre for Canadian Studies. A sufficient number of Council members were present to constitute a quorum.

33 Greig, who for many years has devotedly visited Mrs. Jacobsen, helped her to sort BSC/SBC papers in her possession. I am grateful to Greig for making copies of early minutes and other documents available to me.

34 Published annually since 1962 and twice a year since I99I, the publication and printing costs have constituted the chief expenditure of the Society, and in some years, created temporary deficits at the time of payment of printer's invoices.

35 Instituted in 1987 , the Tremaine Fellowship is offered annually to support the work of a scholar in some area of bibliographical research, including textual studies and publishing history, with particular emphasis on Canada. The Fellowship is in the amount of $\$ 1,000.00$, and is open only to members of the Society.

36 The Amtmann Fellowship, which is in the amount of $\$ 1,500.00$, is offered every three years. It is open to non-Canadians and non-members of the Society. The Fellowship was first awarded in 1992. All Fellowship winners are required to submit a report on completion of the project, which is usually published in the Bulletin.

37 Honorary Life Members: W. Kaye Lamb, Raymond Tanghe, Jaroslav B. Rudnyckyi, Carl F. Klinck, Rev. A.M. Morisset, David Hayne, Mrs. Esther Jacobsen, Bruce Peel, and Patricia Fleming.

38 Individual membership fees, originally set at $\$ 2.00$, have seen a steady increase: \$5.00 (1959); \$10.00 (1970); \$20.00 (I980); \$30.00 (I992). Institutional fees have been augmented also; from $\$ 5.00$ to $\$ 12.00$ (1959); $\$ 25.00$ (I 970 ); $\$ 30.00$ (I 980 ); $\$ 40.00$ (1992). The current fee for student and retired members is \$15.00. Life members originally paid $\$ 50.00$, and now have to pay $\$ 500.00$, and Contributing Members, $\$ 75.00$ yearly. At first included in the Constitution and By-Laws, the fees are now proposed by Council and voted by the members at the Annual Meeting. As membership benefits, members receive the serials published by the Society free of charge. Formerly, the Society's monographs were also distributed free to members. More recently, current and earlier monographs have been sold to members at reduced prices. 
39 A sudden increase in members was achieved in 1989 when the registration fee to the Annual Meeting included a year's free membership.

40 It would perhaps be of interest to quote the late William Cameron's comments. Writing in 1982, he compared the relationship of librarians and bibliographers to two solitudes, the former representing the 'majority culture' and the latter, the 'minority.' Referring to the Society, he noted: '. . . one cannot but be struck by the fact that it alone among "national" bibliographical societies, is very much dominated by the majority culture (witness the Bibliographical Society of America, which keeps librarianship at arms length).' However, he also remarked that '. . recent attention to the concerns of "analytical" bibliography, rather than [to] "enumerative" bibliography, suggests that the minority culture is gaining a voice and a substance within the Society.' The above comments appear at the beginning of Cameron's article, 'The Creation of Canadian-Based Bibliographies of Early Books,' Papers/Cahiers $2 \mathrm{I}$ (1982): 59-8I.

4I The Constitution and By-Laws adopted at the first Annual Meeting of the Society, and subsequent versions, either explicitly or implicitly mention publications. The objects of the Society are noted as: $\mathbf{r}$. To promote bibliographical publications. 2. To encourage the preservation and extend the knowledge of printed works and manuscripts, particularly those relating to Canada. 3. To facilitate the exchange of information concerning rare books. In the Constitution published in Papers/Cahiers I (1962): $3-12$, the text is the same, in section 3 , the word such rare books is added. In the $198 \mathrm{I}$ revised Constitution, published in Papers/Cahiers 20(198I): I I-20, the first paragraph has been expanded to read: I. To promote the study of bibliography and the publication of works of bibliography (whether notes, articles, editions, or books, etc.), with a principal emphasis on those connected with Canada. Paragraph 2 is unchanged. Paragraph 3 shows a minor revision in wording: 3 . To facilitate the exchange of information concerning such manuscripts and books, etc. References to the Society's own publications can be found in Section no. 4 of the By-Laws, adjusted over the years to reflect new titles of serials and revisions to publication and distribution policies.

42 The minutes were consulted in Fonds Marie-Claire Daveluy. Special Collections, National Library of Canada.

43 Some examples of Pierce's generosity are the following. He subsidized the first three issues of the Newsletter which followed the Bulletin in 1955. Two monographs were issued at his expense: no. 4 in the Reprint Series, The Manuscript Book of Oliver Goldsmith, published in 1950; and no. 4 in the Facsimile Series, Cree Syllabic Hymn Book by James Evans, published in 1954. Ryerson Press publications were offered to members at considerable discount or free of charge. Edward A. McCourt's The Canadian West in Fiction (Toronto: The Ryerson Press, 1949/ was offered to members at a $40 \%$ discount, and a note was added on the title page: 'Published under the auspices of the Bibliographical Society of Canada.' Free copies of W.S. Wallace's The Ryerson Imprint: A Checklist of Books and Pamphlets Published by The Ryerson Press Since the Foundation of the House in 1829 (Toronto: The Ryerson Press, 1954) were distributed free 
to members. Pierce even acquired volumes published elsewhere which he considered of interest to members and made them available at reduced prices. An example is: The Standards of Bibliographical Description by C.F. Bühler (Philadelphia: University of Philadelphia Press, 1950).

44 Richard Cockrel, Thoughts on the Education of Youth. Printed by G. Tiffany at Newark, Upper Canada, in 1795 and reproduced in mimeographed form by the Bibliographical Society of Canada. Toronto, Canada, 1949. vi, 9 pp. Reprint Series no. I (Tremaine, 929). This was the first publication of what was intended to be a series of reprints of rare Canadian pamphlets. This early imprint, considered to be the first non-governmental or non-official publication in Upper Canada, is the work of Richard Cockrel (1773?-1829), a Loyalist and pioneer educator, who kept school at various locations in Upper Canada and who was also active as journalist, newspaper publisher, surveyor and prominent Mason. The booklet was printed by Gideon and Silvester Tiffany, printers at Newark, 1794-I 802. As in all future monograph publications in the Reprint and Facsimile Series, it was produced in co-operation: the Library of the University of Western Ontario assisted in the preparation and publication of the pamphlet, and the introduction was written by James J. Talman, University Librarian. The copy of the pamphlet was made available by the Librarian of the University of Toronto, W.S. Wallace, a photostat made from the original at the Library of Congress. There appeared to be no copies in Canada.

45 Représentations par le Corps de Grands Jurés, 1764. Printed by Brown and Gilmore at Québec in 1765 and reprinted in mimeographed form by the Bibliographical Society of Canada. Toronto, Canada, I949. ii, 23 pp. Reprint Series no. 2 (Tremaine 67). As a second offering to its members, the Society issued a reprint of a publication, the very existence of which had been at times questioned, but which actually constitutes a section of the first book printed in Québec, namely the French text of the 'Presentments' of the Grand Jury at Québec, the first printers in Québec City. Described by Tremaine as the 'first piece of political propaganda printed in Canada,' it had been issued at the expense of James Johnston, a Quebec merchant, foreman of the first Grand Jury of the Court of General Quarter Session in Québec, and was an attack by a small group of English merchants on the powers of French-speaking Catholics and critical of British authorities in the Colony. W. Stewart Wallace, Librarian of the University of Toronto, provided a photostat copy from the original at Laval University. The introduction is signed 'F.L.' (Fred Landon). The pamphlet was produced at the University of Western Ontario.

46 It is interesting to note that according to the Council minutes in 1948 , the University of Toronto Press had 'unofficially' invited the Society to co-operate in the publication of Tremaine's Bibliography of Canadian Imprints, I752-I800. Although Council agreed that this publication 'would establish the Society's reputation firmly,' the BSC was not in the position to offer financial support.

47 The Bulletin appeared in an $8 \times \mathrm{II}^{\prime \prime}$ format, a mimeographed typescript, the pages stapled together, from two to seven pages in length, and variously titled News Letter, Bulletin, or both simultaneously. At one point, the name of the 
Society appeared both in English and French, the last issue bearing the title Actualité-Bulletin 9 Newsletter. The issues were not always numbered or dated; in fact, the first issue examined had 'Bulletin no. I, May 1949' added by hand. During the years of Father Morisset's presidency, the text was bilingual, in a mixture of English and French in alternate paragraphs.

48 Thus, in the April 1950 issue (no. 3), Bruce Peel announced that he hoped to complete the manuscript of his 'Bibliography of the Prairie Provinces' by the summer. Freda F. Waldon reported having completed her 'Bibliography of Canadiana Published in Great Britain to 1763 .' It took many years and editorial work by BSC member William F.E. Morley, before Waldon's important bibliography was actually published, the typescript which Waldon had given to the National Library having been lost for some time: Bibliography of Canadiana Published in Great Britain, I5 19-1763 / Bibliographie des ouvrages sur le Canada publiés en Grande Bretagne entre I5 19-1763 (Toronto: $\mathrm{ECW}$ Press in collaboration with the National Library of Canada, 1989).

49 James Anderson, Sawney's Letters. First printed at the office of the Cariboo Sentinel at Barkerville, on Williams Creek, B.C. in I 868 and reproduced in mimeographed form by the Bibliographical Society of Canada, with an introduction by W. Kaye Lamb, Dominion Archivist. (Toronto, Canada, I950). v, 26 pp. Reprint Series no. 3. A rare British Columbia imprint, it reflects life in the Gold Rush period of the 1860 s in the colourful mining community in the Cariboo District. It is in verse form, written in the Scottish dialect by James Anderson (1838-1923), a Scotsman who spent some eight years at Barkerville. His poetry had been published in some issues of the Cariboo Sentinel. The collected poems were published in 1868 by the printer of the Sentinel, using the first press brought into British Columbia.

50 The Manuscript Book of Oliver Goldsmith. Description and comment by E. Cockburn Kyte (Toronto, Canada, 1950) 4, I7 pp. Reprint Series no. 4. Goldsmith (I794-I 86I) was a grand-nephew of the Anglo-Irish poet. Rising Village: A Poem (first ed., London, 1825; first Canadian ed., Saint John, N.B., 1834) is considered the first volume of verse published in Canada by a native-born writer. The Reprint is based on a manuscript acquired by Edith Chown Pierce (Lorne Pierce's wife) for the Queen's University Library. This booklet reproduced poems from the small manuscript notebook.

5 I Aux citoyens et habitants des villes et des campagnes de la Province de Québec (Québec, Brown, 1785). (Toronto, Canada, I95 I) vi, I 5 pp. Facsimile Series no. I (Tremaine 453). Demanding reforms, in particular the repeal of the Québec Act of 1774 , this pamphlet takes the form of an open letter, dated November 1784 , to the inhabitants of the towns and country districts of Québec, explaining the point of view of the so-called Reform Committee. The pamphlet was obtained from the Bibliothèque Saint-Sulpice in Montréal. W. Kaye Lamb provided the photostat reproduction. Various departments of the University of Ottawa participated in the production of the facsimile. The introduction, in French, is by Father Auguste-M. Morisset.

52 Stephen Dickson, The Union of Taste and Science: A Poem, to Which Are 
Subjoined a Few Elucidated Notes (Quebec: Neilson, 1799). (Toronto, Canada, I952) v, I8, [3] pp. Facsimile Series no. 2. (Tremaine I I24). The original of this publication is described by Tremaine as 'a handsome production printed in large ... type with a brilliant impression on fine heavy wove paper,' a fine example of early Canadian printing. One of the earliest volumes of verse published in English in Canada, this work was printed in a small edition for the author, a visiting Englishman, to honour his friends, Governor Prescott ('science'), and his wife ('taste'). He added 'elucidating notes' on classical and other allusions in the text. Lamb made available a photostat copy from a microfilm of the pamphlet, the original being held by the Bibliothèque Municipale in Montréal. The introduction is by the book collector from Richmond Hill, Ontario, Fred G. Ketcheson. Assistance in the preparation of the pamphlet was provided by the University of Ottawa. The financial statement presented at the 1952 Annual Meeting as reported in Bulletin no. 9, 1952, shows that the printing of nos. I and 2 of the Facsimile series cost $\$ 200.00$ a large sum when the balance in the bank account was reported as $\$ 370.15$.

53 J.C. Major, The Red River Expedition (Winnipeg: Laurie, I 870 ). (Toronto, Canada, 1953) vii, $28 \mathrm{pp}$. Facsimile Series no. 3 (Peel 380). This is the first pamphlet published in the Red River Settlement, and considered to be the first literary work published in the Prairie Provinces. It is an account, in verse form, of the military expedition sent by the Canadian government to Red River early in $\mathrm{I} 870$, under the command of Col. Garnet Wolseley. The printer, Patrick Gammie Laurie, came to Red River in 1869 , and later was active as printer and publisher of newspapers in Manitoba and Saskatchewan. Peel's introduction brings out many interesting facts and events relating to early printing in the area. The facsimile was reproduced from the only surviving copy at the Public Archives of Canada.

54 James Evans, Cree Syllabic Hymn Book (Norway House, I84r). (Toronto, Canada, I954) 9, 23 pp. Facsimile Series no. 4 (Peel ro3). Translated and printed by the Rev. James Evans, Wesleyan Missionary at Norway House, Hudson's Bay Territory, in Cree syllabics devised by Evans. The earliest book extant printed in the Canadian Northwest on a converted fur press, the type was cast by Evans from lead obtained partly from the lining of tea chests, partly from bullets. The facsimile was made from one of the three surviving copies at Victoria University in Toronto (a gift from a niece of James Evans). The introduction is by Margaret V. Ray, Librarian at Victoria University. It is accompanied by a translation of the text into English by Archdeacon Raymond B. Horsefield, of Flin Flon, Manitoba. Le Droit, the Ottawa French-language newspaper, is indicated as having printed the facsimile. Some 300 copies were printed.

55 The British American Almanack for the Year 1792 (Saint John, 1791). (Toronto, Canada, 1953) vi, 5op. Facsimile Series no. 5 (Tremaine 688). This early New Brunswick imprint was published by John Ryan and Christopher Sower, two of the first printers of New Brunswick, both having come up from the United States. They issued newspapers and almanacs before joining forces to produce the 1792 Almanack. The facsimile was reproduced from a microfilm made by 
the National Library from the only complete copy known, held by the L.P. Fisher Library in Woodstock, New Brunswick.

56 Major Richardson's Kensington Gardens in 1830 . Edited, with an introduction by Carl F. Klinck. (Toronto, Canada, I957) xiii, 32 pp. Facsimile Series no. 6. Published anonymously by the Canadian writer Major John Richardson (I796I852), while in England as an army officer on half pay, under the title Kensington Gardens in 1830: A Satirical Trifle (London: Marsh and Miller, 1830). Klinck, not only edited the facsimile, he arranged for its reproduction. In his introduction he notes having seen a copy at the British Museum. No copies were located in North America. In the Preface, Pierce describes it as one of the rarest titles in Canadian literature. The facsimile was printed from a microfilm copy at the University of New Brunswick Library.

57 David William Foley was at the time Librarian at the Royal Military College at Kingston (1954-6I). Later he became Librarian of the University of Manitoba $(1961-9)$ and was President of the Canadian Library Association in 1964-5. He also taught at the School of Library and Information Studies of the University of Alberta in Edmonton.

58 The first issue, no. I (Spring 1955), was followed by no. 2 (Spring 1956) and no. 3 (Autumn 1956). No Newsletter was published in 1957, thus no. 4 came out in the spring of 1958 . The volume numbering started with the September 1959 issue (vol. I, no. I) and from then on, until I962, four issues a year were published in September, December, March and June. The first three issues are noted as having been 'privately financed' (no doubt by Pierce), but later issues were paid for out of the Society's funds. The format was a definite improvement over the Bulletin: the text still mimeographed (in a bluish tint), the pages still stapled together, but printed on better quality paper. The lettering on the masthead, 'The Newsletter. Bibliographical Society of Canada,' is in white on a dark blue background. From issue no. 3, the name of the Society also appears in French. The first two issues were in legal size, later ones in an $8 \mathrm{x} \mathrm{II}$ " format, three to twenty pages in length.

59 'A Special Issue in Honour of Dr. Lorne Pierce, Honorary President of the Bibliographical Society of Canada, on the Occasion of his Reitrement as Editor of the Ryerson Press (February I, 1960),' Newsletter 3, no. 2 (December 1959). The issue contained: a list of Pierce's degrees and honours; Raymond Tanghe's 'Lorne Pierce, Fondateur de la Société Bibliographique du Canada'; W.S. Wallace's 'Lorne Pierce, Editor of the Ryerson Press'; H. Pearson Gundy's 'The Edith and Lorne Pierce Collection at Queen's University'; a list of recipients of the Lorne Pierce Medal from 1926 to 1959, awarded yearly by the Royal Society of Canada, to an outstanding Canadian author. A bibliography of Pierce compiled by Frank Flemington of The Ryerson Press was referred to, but not included in the issue. Sadly, in a later issue, the Newsletter announced the death of Pierce, which occurred in November $196 \mathrm{I}$.

60 Early Printers and Printing in the Canadas (Toronto: Bibliographical Society of Canada, 1957l, $54 \mathrm{pp}$. Read before the members of the Society at its Annual Meeting in Niagara Falls in 1956, it was first presented to the Saturday Club, 
Queen's University, in March of that year, and later revised and enlarged. It covers the beginnings of printing and publishing in Upper and Lower Canada. The work was printed at Kingston with the assistance of the editorial staff of the Queen's Quarterly, of which Gundy was the Editor. 300 copies were printed at a cost of $\$ 315.00$ for typing, printing, and binding. The book enjoyed good sales, and was re-edited in 1964 .

6I A slim bilingual volume of 206 pages, bound in blue buckram, it listed I,665 bibliographies (mainly monographs, including some 75 I author bibliographies, mostly contributed by library schools). The entries are arranged alphabetically by author or title within twenty-nine broad subject categories. Access is provided by three indexes by compiler, author as subject (for author bibliographies), and subject.

62 Supplement I960 \& I96I (Toronto: Bibliographical Society of Canada, 1962). 24 pp.; Supplement 1962 \& 1963, comp. Madeleine Pellerin (Toronto: Bibliographical Society of Canada, 1964). 27 pp.; Supplement I964 \& I965, comp. Madeleine Pellerin (Toronto: Bibliographical Society of Canada, 1966). 32 pp. The supplements were distributed free to members. Additional copies were sold at $\$$ I.oo apiece.

63 The Papers/Cahiers were published annually until I99I when two issues a year began to be published. The Papers/Cahiers took over from the Newsletter the publication of the minutes of the Annual Meetings (until 1984) and Membership Directories (until 1978). Articles in both English and French are accepted, and since 1994, the journal has carried summaries of the articles in either language. The articles have treated almost exclusively of Canadian topics. Indexes have been regularly issued, prepared by Indexers to the Society (Peter Greig, Marilyn Flitton, and Jan Roseneder). The journal is now also indexed in the MLA International Bibliography and its contents listed in the 'Recent Periodicals Section' of the Library. In 1968, a Books in Review section was added. The review editors have been: W.F.E. Morley (I968-8I); David Kotin (1982-5); Bruce Whiteman (1985-7); Carl Spadoni (1988-93); and Michel Brisebois (1994-). Since 1988, there has also been a French Book Review Editor: Yvan Lamonde (1988-90) and François Melançon (I99I-).

64 Fellow of the Royal Society since 1970; Associate Editor of the University of Toronto Quarterly, responsible for Letters in Canada, 1969-76; General Editor of the Dictionary of Canadian Biography, 1965-76; author (with Marcel Tirol) of Bibliographie critique du roman Canadien français, $1837-1900$ (1968), as well as of many articles in scholarly journals. Hayne was the subject of a festschrift in his honour in 1986: Solitude rompue: textes réunies par Cécile CloutierWojechiechowska et Réjean Robidoux, en hommage à David M. Hayne (Ottawa: Éditions de l'Université d' Ottawa, I986).

65 Editors who have followed Hayne have been: Edith G. Firth $(1973-6) ;$ H. Pearson Gundy (I977); Elizabeth Hulse (1978-82); Patricia Stone (I983-7); Bruce Whiteman (1988-93); and Carl Spadoni (1994-). Since 1986, an Editorial Board has assisted the editor in the assessment of the articles submitted for publication.

66 Mary Markham Brown, An Index to the Literary Garland. Montreal, I 838-I95 I 
(Toronto: Bibliographical Society of Canada, 1962). x, 61 pp.

67 H. Pearson Gundy, Book Publishing and Publishers in Canada before 1900 (Toronto: The Bibliographical Society of Canada / La Société bibliographique du Canada, 1965).iv, $63 \mathrm{pp}$. The text was originally intended to be a chapter entitled 'The Book Store as Publisher,' in a book projected by Pierce, on publishing and bookselling in Canada, for the Canadian Book Publishers Council. Nothing came of this venture due to Pierce's death in I96r. Gundy's small book was published in an edition of 500 copies.

68 A.G. Gilbert, From Montreal to the Maritime Provinces and Back ... Introduction by Douglas G. Lochhead. (Toronto, Canada: The Bibliographical Society of Canada / La Société bibliographique du Canada, I967), 5, 63 pp. A Centennial Publication in Facsimile . . Facsimile Series no. 7. First published as ten 'letters' in the Montreal Evening Telegraph by Alexander Glen Gilbert (1840-1913), a young reporter on assignment to Nova Scotia and New Brunswick to describe to the readers of the paper how this part of the country 'celebrated or endured the birth of a new country.' The facsimile was reproduced from the original in the Legislative Library of Nova Scotia, provided to the Society by the Librarian, Shirley Elliott. 500 copies were published at a cost of $\$ 598.00$. The red paper wrapper and the title page are decorated with typographic ornaments.

69 G.O. Corbett, Notes on Rupert's America. Introduction by Bruce Peel. (Toronto, Canada: The Bibliographical Society of Canada / La Société bibliographique du Canada, 1967) 7, 88 pp. A Centennial Publication in Facsimile ... Facsimile Series no. 8. (Peel 269). The Notes describe the area then still governed by the Hudson's Bay Company whose policies Corbett, a medical missionary, criticized. Corbett also gave information on the resources of this vast area. The main text is preceded by the reproduction of the unique copy of Corbett's A Few Reasons for a Crown Colony, considered to be the first imprint in the Red River Settlement. The latter is located at the Provincial Archives of Manitoba. The facsimile was reproduced from a copy of the Notes in the Elizabeth Dafoe Library of the University of Manitoba. 500 copies were printed at a cost of $\$ 730.00$, in the same format as the other Centennial Facsimile, except for the light blue wrapper.

70 Bibliography of Canadian Bibliographies / Bibliographie des bibliographies canadiennes. 2nd ed. rev. and enl., comp. Douglas G. Lochhead, index by Peter E. Greig. (Toronto: Published in Association with the Bibliographical Society of Canada by the University of Toronto Press, 1972).xiv, $312 \mathrm{pp}$. The second edition of the Bibliography contained 2,323 entries, incorporating ments. The major change was the rejection of the subject arrangement in favour of an alphabetical listing by author or title, the subject access being provided by the elaborate bilingual index. As in the first edition, all bibliographies included had a Canadian connection, either by subject, compiler or geographical location. The attractive volume is bound in red buckram, with a pale grey dust jacket. It was published in an edition of 2,000 copies, to be sold at $\$ 20.00$ each.

7 I Printed in some 10,000 copies, the brochure was widely distributed to pertinent institutions and organizations. To this day, the brochures have continued to be the most important vehicle for publicity purposes. 
72 A Bibliographical Study of Major John Richardson. With an Introduction by Dr. Derek F. Crawley (Toronto: Bibliographical Society of Canada, 1973) xxviii, I44 pp. The first major self-funded monograph, published entirely at the expense of the Society, it was printed by the University of Toronto Press, and seen through the press by Lochhead. 750 copies were printed at a cost of $\$ 2,770.00$ and sold at $\$ 10.00$ a copy. Members received their free copies early in 1974. See also 'A Bibliographical Study of John Richardson,' Papers/Cahiers 4 (I965): 2 I-88.

73 Specimen of Printing Types and Ornaments in Use at the Printing Office of Lovell et Gibson, St. Nicholas Street, Montréal. (Toronto, Canada: The Bibliographical Society of Canada / La Société bibliographique du Canada, 1975). Facsimile Series no. 9. 750 copies were printed at the University of Toronto Press at a cost of $\$ 4,007.00$, from a rare 1846 copy in Hugh Anson-Cartwright's possession. Members received the volume free of charge early in I976. A copy was sent to the firm, still at the same address in Montréal. In his 'thank you' note, the firm's president, Robert $M$. Lovell, said that he had been unaware that his great grandfather had issued such a volume.

74 Marilyn G. Flitton, comp., An Index to the Canadian Monthly and National Review and to Rose-Belford's Canadian Monthly and National Review, I872I 882 (Toronto: Bibliographical Society of Canada / Société bibliographique du Canada, 1976), xxiv, 15 I pp. Printed for the Society by the University of Toronto Press at a cost of $\$ 4,159.00$.

75 For the Proceedings, see note 17.

76 In 1976, for example, Lochhead proposed a collection of previously published essays on Canadian bibliography. The work would have some two hundred and fifty pages, and the cost of publication was estimated at $\$ 6,000.00$. Applications for funding were submitted to agencies such as the Ontario Arts Council and Wintario, but the requests were turned down. The project was revived periodically into the early 1980 , but was never realized. Some of the essays from the proposed collection were later issued as articles in the Papers/Cahiers, all with introductions by Lochhead.

77 'The Bibliography of Canadian Bibliographies: Some Proposals for Its Future,' Papers/Cahiers 16 (1977): 8-16.

78 Bulletin, n.s, issued in an $8 \mathrm{x}$ I I" format, was first mimeographed, but when laser-printing facilities became available to the editors, it appeared in an increasingly attractive format, decorated with borders and even cuts. The BSC logo, a stylized hand-press, has appeared on the masthead since 1974. Bulletin appears twice a year, in May and November, and the 'official' contents take up most of the space: in the May issue, the announcement of the Annual Meeting and preliminary programme are published, as well as the minutes of the previous year's meeting. The proposed slate of officers and Council members are also included, and any amendments to the Constitution, or other important items to be voted on at the Annual Meeting. As well, the May issue carries names of the Tremaine Medal and Fellowship winners, reports of work done by the previous year's Fellowship winners, travel subsidy policy statements and forms for requesting subsidies for travel to conferences. The November issue usually 
includes: a preliminary announcement of the next Annual Meeting and a call for papers; the detailed Treasurer's Report of the previous Annual Meeting; a list of Officers and Council; a call for nominations to Council and Executive; a call for nominations for the Tremaine Medal; and application forms for Fellowships. Bulletin also contains: brief information of interest to members, regarding publications (by members, and other books or periodicals of interest); news on organizations and meetings; new journals in the field; news of members, etc. In the 1980 s, lists of projects funded by ssHrC were included also.

79 Bruce Braden Peel, long-time member of the Society, its President from I 970 to 1972, Honorary Life Member since 1993. A leading figure in Canadian librarianship, he had a long and successful career at the University of Alberta Libraries, and was President of the Canadian Library Association in 1969-70. His bibliographical works on the Canadian West, which include the Bibliography of the Prairie Provinces to 1953 (first ed., 1956; 2nd ed., 1973), received recognition of achievement with the Marie Tremaine Medal in 1975 . He is also the author of many studies on regional history and printing and publishing in the West and Northwest, including the work of the missionary presses in native languages.

80 When the Publications Committee and the Council decided to get involved with the project, a special ad-hoc Sub-Committee of the Council was set up in the Spring of 1983 'to review the nature of and the necessity for a third edition of the formally approved by Council in $1977 . '$ The Editor of вСв 3 resigned, finding his position 'untenable since three groups were involved in re-planning the BСB and major decisions seemed to be under consideration without reference to the Editor.'

8I Gloria Strathern, Professor at the University of Alberta, Faculty of Library and Information Studies, and President of the Society from I98I to 1983 , is the author of many important bibliographies of British Columbia and Alberta, such as Navigations, Traffiques and Discoveries, I774-1848 (1970); Alberta, 19541979: A Provincial Bibliography (1982) a continuation of Peel's bibliography; Alberta Newspapers, 1880-1982: An Historical Directory (1988). She was awarded the Tremaine Medal in 1989.

82 David B. Kotin, comp., Reader, Lover of Books, Lover of Heaven: A Catalogue Based on an Exhibition of the Book Arts in Ontario, with a checklist of Ontario private presses by Marilyn Rueter and an introduction by Douglas G. Lochhead. (Willowdale, Ont.: North York Public Library, 1978); David B. Kotin and Marilyn Rueter, comp., Reader, Lover of Books: The Book Arts in Ontario (Willowdale, Ont.: North York Public Library, I98I), vol. 2.

83 Ernie Ingles, ed. and comp., and Gordon R. Adshead, principal researcher and comp., Bibliography of Canadian Bibliographies / Bibliographie des bibliographies canadiennes 3rd ed., updated, rev. and enl. (Toronto: University of Toronto Press, 1994). xliii, [5], I 178 pp. In this edition, the copyright holders are indicated as being Ernie Ingles and the Bibliographical Society of Canada.

84 The terms of the award, as first published in Papers/Cahiers 9 (1970): 8, are as follows: 
The medal shall be known as the Marie Tremaine Medal of the Bibliographical Society of Canada. It shall be a gold medal (actually bronze). It shall be awarded beginning in 1970, preferably to a member of the Bibliographical Society of Canada, or to a citizen of Canada, for outstanding service to Canadian bibliography and for distinguished publication in either English or French in that field.

In the same issue (pp. 9-Io), the first medal was also illustrated. The original medal, designed by Peter Dorn, was a square plaque with the logo of the Society and an inscription etched in Cartier type face. A new medal was designed in 1985 by Dora de Pédery Hunt, which bears on one side the portrait of Marie Tremaine. It is illustrated in Papers/Cahiers 25 (1986): 8. Since 1985, the Tremaine Medal has been awarded annually, if qualified candidates are nominated. From 1970, sixteen bibliographers have received the medal. An updated list of Tremaine winners is published in the Society's brochure.

85 For papers presented at the first Colloquium, see Papers/Cahiers 10 (197 I).

86 On this topic, see also Liana Van der Bellen, 'Bibliographie, bibliography, bibliologie: quelques remarques sur la terminologie' in Livre, bibliothèque et culture québécoise: Mélanges offerts à Edmond Desrochers, s.j. (Montréal: ASTED, I977), vol. I, 8I-97.

87 Some twenty years later, another noted American bibliographer, Thomas G. Tanselle, invited to speak at the 1992 Third National Conference on the State of Canadian Bibliography, conceded that, at least in the area of imprint bibliography (referring to Patricia Fleming's Upper Canadian Imprints, I 8OI-I $84 \mathrm{I}$ and her Atlantic Canadian Imprints, I 80I-I 820), Canadians had indeed something to teach their American colleagues!

88 For the Proceedings, see note $\mathrm{I} 8$.

89 For Colloquim III Proceedings, see note 17.

90 For the Proceedings, see note 18.

9I In I 994 the monographs reproduced by СІнм between 1978 and 1988 contained full-text microfiche of some 57,800 imprints of Canadiana published between I 559 and 1900 (Phase I). An additional 5,000 monographs have recently been microfilmed. Phase II of the project, the microfilming of pre-1900 serials, is discussed in Pam Bjornson and Thomas B. Vincent's 'Canadian Serials to I900: CIHм's Micropreservation Project, Phase II,' Serials Librarian 26, nos. 3-4 (July I995). See also the reports in Facsimile/Fac-similé, сін M's newsletter.

92 A separately issued bibliography was published at the time of the 1978 Annual Meeting of the Society to complement the theme of the meeting: Dorothy E. Ryder, comp., The Canadian West $\Theta$ the North: A Bibliographical Overview (Edmonton: published for the Bibliographical Society of Canada / Société bibliographique du Canada by the University of Alberta, 1978), I 3 pp.

93 For the Proceedings, see note 18.

94 In 1993 Estivals edited an anthology on all aspects of bibliography in cooperation with other French scholars: Robert Escarpit, Henri-Jean Martin, Jean Meyriat, François Richardeau et al, Les sciences de l'écrit: Encyclopédie internationale 
de bibliologie (Paris: Retz, I993).

95 The Institute on Canadian Bibliography was created by the Society and the National Library in 1993. It held its first summer course at the National Library on 'Analytical Bibliography for Canadian Studies,' I6-20 August 1993. Coordinated by Gwynneth Evans, Director of External Relations at the National Library, and by Patricia Fleming, the sessions offered lectures and workshops from a selected group of bibliographers and specialists on book production, typography, paper, binding, and analytical and descriptive bibliography. The first course attracted some thirty participants. The course was offered again by Fleming at the National Library in August 1995.

96 A Toronto Centre of the Book has recently been established at the University of Toronto. In 1995 the National Steering Committee for a National Centre for the Book in Canada (a group of scholars, bibliographers, and librarians) conducted a survey on the 'feasibility of establishing a national Centre of the Book in Canada.' One of the options related to an institutional affiliation of the proposed centre with the National Library. 